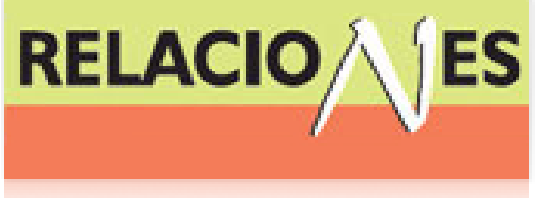

Relaciones. Estudios de historia y sociedad ISSN: 0185-3929

relacion@colmich.edu.mx

El Colegio de Michoacán, A.C

México

Lizama Silva, Gladys

Inventario de la fábrica textil La Escoba, Guadalajara, Jalisco, 1901

Relaciones. Estudios de historia y sociedad, vol. XXXII, núm. 128, 2011, pp. 119-206

El Colegio de Michoacán, A.C

Zamora, México

Disponible en: http://www.redalyc.org/articulo.oa?id=13721074005

Cómo citar el artículo

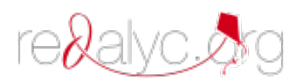

- Número completo

- Más información del artículo

Página de la revista en redalyc.org

Sistema de Información Científica

Red de Revistas Científicas de América Latina, el Caribe, España y Portugal Proyecto académico sin fines de lucro, desarrollado bajo la iniciativa de acceso abierto 


\section{DOCUMENTo}

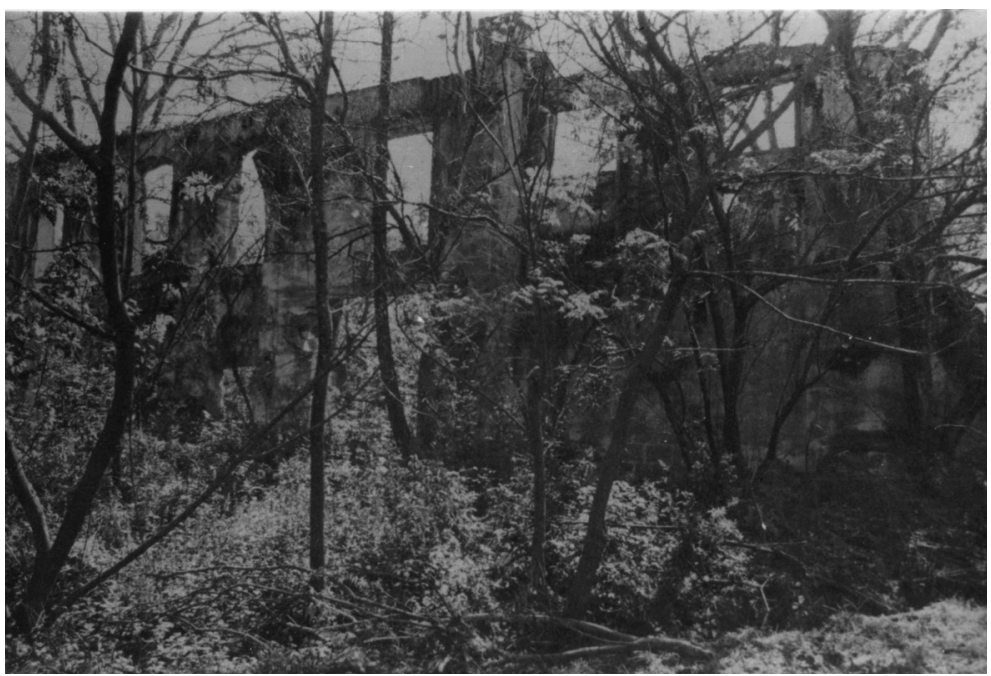

RELACIONES 128, OTOÑO 2011, VOL. XXXII 


\title{
Inventario de la fábrica textil La Escoba, Guadalajara, Jalisco, 1901
}

\author{
Gladys Lizama Silva* \\ UNIVERSIDAD DE GUADALAJARA
}

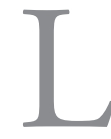

a trayectoria de investigación del origen y desarrollo de la fortuna de la familia Martínez Negrete durante el siglo xIx en Guadalajara, me ha llevado por caminos ignotos pero formidables, uno de ellos fue hallar el Juicio de Quiebra de Francisco Martínez Negrete Alba, fechado en $1901 .{ }^{1}$ En ese expediente de más de 750 fojas encontré el inventario de la fábrica textil La Escoba, propiedad de este empresario desde 1897 hasta 1901 . Hoy presento al lector este testimonio invaluable para la historia del patrimonio industrial $^{2}$ y de la tecnología de Jalisco, que permaneció silencioso en la multiplicidad de cajas que contenían la documentación proveniente del Archivo del Supremo Tribunal de Justicia, Ramo Civil, que personal especializado de la Universidad de Guadalajara tiene en proceso de clasificación.

La mecánica seguida ha sido lenta y de sumo cuidado en la captura de la información cuantificable de todos los inventarios que contiene el expediente. ${ }^{3}$ En el caso de la fábrica textil La Escoba,

*gladysli@cencar.udg.mx

${ }^{1}$ Biblioteca Pública del Estado de Jalisco (en adelante BPEJ), Legajos del Inventario de la Quiebra de Francisco Martínez Negrete Alba, Liquidación Judicial, 1901, Archivo Histórico del Supremo Tribunal de Justicia (AHSTJ), Ramo Civil, caja 1901-12, Exps. 157180 y 157193.

${ }^{2}$ Véase Victoria Novelo Oppenheim, "Herencias culturales desconocidas, el caso del patrimonio industrial mexicano", Cuadernos de Antropología Social, núm. 21, Buenos Aires, enero/julio, Versión On-line, ISSN 1850-275X, 2005.

${ }^{3}$ En caso de declaratoria de quiebra, por ley debía efectuarse un inventario de todos los bienes del quebrado, a fin de establecer el valor total de los mismos, para luego proceder a su venta o remate y con lo obtenido pagar a los acreedores. 
conservé el orden de presentación de los rubros inventariados en el expediente original, pero en vez de listado ordené la información en cuadros que permiten una mejor comprensión de los datos. Revisé en diccionarios especializados ${ }^{4}$ los nombres de objetos, herramientas, maquinaria y enseres, para cerciorarme que no hubiera un error de transcripción mío o del escribiente original que hizo el inventario. La fecha en que se efectuó el inventario fue el 29 de marzo de 1901, pero supongo que demoró algunos días, sin embargo, todos los cuadros tienen la misma fecha para guardar fidelidad al documento original. Luego busqué noticias y reseñas que informaran de la evolución histórica de la fábrica: hay poco. Todo lo encontrado en la escasa bibliografía está sintetizado a continuación. ${ }^{5}$

La fábrica La Escoba, fue construida en los terrenos de la hacienda La Magdalena, ubicada al noroeste del partido de Zapopan a cuatro leguas $^{6}$-aproximadamente entre diez y seis a diecisiete kilómetros $-^{7}$ de Guadalajara. Originalmente tuvo la forma de un triángulo isósceles de 618 varas $(517.88 \mathrm{~m})$ por un lado, 618 por otro y 716 varas $(600 \mathrm{~m})$ por el siguiente, con una superficie total de 180,341 varas cuadradas (12.66 hectáreas). ${ }^{8}$ Disponía de fuentes de agua propias de la hacienda La Magdalena que provenían del río Blanco y que debían mover "dos mil malacates" para producir hila-

${ }^{4}$ Francisco Casa Aruta, Diccionario de la industria textil, Barcelona, Ed. Labor, 1969. Aurelio Ruiz Miyares, La tintorería al alcance de todos, Tercera edición corregida y aumentada con todo lo más moderno que en el arte del tintorero se ha inventado por Pedro Barralt, Barcelona, Francisco Savater Editor, 1903.

${ }^{5}$ Con seguridad existe más material que el aquí consignado, pero es información repetida y en algunos casos errónea. Para entender el proceso histórico de modernización de la industria textil me apoyé en Historia de la tecnología desde 1750 hasta 1900 de T. K. Derry y Trevor Williams, México, Siglo XXI Editores, vol. 3, 2006, 812-853.

${ }^{6}$ Archivo Histórico de Jalisco (en adelante AHJ), protocolo de Mariano Hermoso, vol. 16, 27/06/1844, ff. 164 y 167v. En la foja 165 del mismo documento dice que está distante cinco leguas de Guadalajara.

${ }^{7}$ Para la conversión de leguas a kilómetros se usó el Diccionario de pesas y medidas mexicanas antiguas y modernas de 1908 de Cecilio A. Robelo, edición facsimilar, México, Ciesas, 1997.

${ }^{8}$ AHJ, Mariano Hermoso, vol. 16, 27/06/1844, f. 167v. Véase Diccionario...., Cecilio A. Robelo, op. cit.

${ }^{9}$ Malacate es un término de origen nahua (malácatl) que tiene dos significados: huso de hilar y máquina a manera de cabrestante que tiene el tambor en lo alto y debajo los 
dos. En los primeros años se construyó La presa El Cedral que existe hasta hoy, a pesar que el edificio e instalaciones de La Escoba tienen otros usos.

Según la documentación procedente de protocolos notariales ${ }^{10}$ el origen de la compañía que dio forma a la creación de la fábrica La Escoba data de 1840 cuando Manuel Escandón, como socio capitalista residente en ciudad de México y Manuel Olazagarre, originario de Panamá pero residente en Guadalajara, convinieron en echar andar el proyecto de fabricación de hilados de algodón en los terrenos de la hacienda La Magdalena, propiedad de Olazagarre, quien fungió como socio industrial a cargo de la construcción del edificio y las labores administrativas de la institución recién creada; esta contribución se estimó en treinta por ciento del valor total de la compañía. Al poco tiempo se agregó un nuevo socio: Francisco Vallejo, residente en ciudad de México, el cual aportó \$20,000.

En 1842, con tres socios ad portas la construcción ya estaba comenzada y comprendería al final del proceso: "presa, acueducto, edificio principal, casa del director, almacenes, habitaciones de operarios, maquinaria con dos mil malacates en movimiento y algodón suficiente para las labores de los dos primeros meses". ${ }^{11}$

En 1844, se formaliza una nueva sociedad para la explotación de la fábrica La Escoba, ahora con nuevos socios que se presentan en el cuadro de la siguiente página.

No sólo hubo \$212,000 de capital dinero reunido, sino un poco más; Manuel Olazagarre mantuvo la aportación adicional estimada en treinta por ciento del total del negocio, que era como dije más arriba, la propiedad de los terrenos de la hacienda La Magdalena, las

controles del motor que lo mueve, Vocabulario esencial mexicano. Léxico de las cosas de México, César Macazaga, Cosmos, 1999, 230; véase también María Moliner, Diccionario del uso del español, tomo II, sexta edición, Gredos, 2006, 240.

${ }^{10}$ AHJ, Protocolo de Mariano Hermoso de 24/06/1844, vol. 16, ff. 164 a 170, que transcribe las escrituras públicas firmadas por los socios en 1842, 1843 y 1844 en ciudad de México y la que formaliza la compañía en 1844 en Guadalajara. Toda la descripción que sigue está hecha con base en este documento, que citaré adicionalmente sólo si es necesario.

${ }^{11}$ Idem, f. 165. 
Accionistas de la fábrica La Escoba, 1844

\begin{tabular}{llcc}
\hline $\begin{array}{l}\text { Nombre del } \\
\text { accionista }\end{array}$ & \multicolumn{1}{c}{ Residencia } & $\begin{array}{c}\text { Monto de } \\
\text { capital aportado }\end{array}$ & Porcentaje \\
\hline Manuel Escandón & Ciudad de México & 132,000 & 62.28 \\
Francisco Vallejo & Ciudad de México & 20,000 & 9.43 \\
Manuel Olazagarre & Guadalajara & 20,000 & 9.43 \\
Sótero Prieto & Guadalajara & 20,000 & 9.43 \\
Julio Moyssard & Guadalajara & 20,000 & 9.43 \\
TOTAL & & 212,000 & 100.00 \\
\hline
\end{tabular}

Fuente: AHJ, Protocolo de Mariano Hermoso de 24/06/1844, vol. 16, f. 167.

aguas de las cuales disponía y toda la piedra y materiales de construcción que hubiera en la misma. Por ello en esta nueva sociedad él mantuvo su carácter de socio industrial con las funciones de dirección, administración y toma de decisiones económicas en todas las actividades necesarias para echar andar la fábrica, salvo en la adquisición de maquinaria en la que fue necesario el acuerdo de los demás socios capitalistas. Los integrantes de esta compañía se obligaron a no vender la fábrica y acordaron que si alguno de ellos quisiera hacerlo sólo podía realizar la venta de la acción por el monto de capital aportado.

$\mathrm{Al}$ año siguiente, en 1845 , se firmó una nueva escritura pública ${ }^{12}$ que invalidó la anterior y que estableció los siguientes acuerdos: 1) Manuel Olazagarre renunció como socio industrial por lo cual la compañía le indemnizó con $\$ 22,884$ por la cesión definitiva de los terrenos, aguas y materiales de la hacienda La Magdalena donde estaba construida la fábrica, que en adelante serían propiedad absoluta de la sociedad. 2) La nueva se formó con los siguientes socios capitalistas:

${ }^{12}$ AHJ, Protocolo de Mariano Hermoso, vol. 17, 28/04/1845, ff. 69 a 73v. La descripción que sigue está hecha con base en este documento. 
Accionistas de la fábrica La Escoba, 1845

\begin{tabular}{llcc}
\hline Nombre del accionista & Residencia & $\begin{array}{c}\text { Monto de capital } \\
\text { aportado }\end{array}$ & Porcentaje \\
\hline Manuel Escandón & Ciudad de México & 127,180 & 52.65 \\
Manuel Olazagarre & Guadalajara & 41,984 & 17.38 \\
Francisco Vallejo & Ciudad de México & 20,784 & 8.61 \\
Julio Moyssard & Guadalajara & 20,784 & 8.61 \\
Sótero Prieto & Guadalajara & 20,784 & 8.61 \\
Joaquín Davis & Guadalajara & 10,000 & 4.14 \\
TOтAL & & 241,516 & 100.00
\end{tabular}

Fuente: AHJ, Protocolo de Mariano Hermoso, vol. 17, 28/04/1845, f. 70.

Como se puede observar, el valor del capital de la sociedad que explotó la fábrica La Escoba aumentó en 8.77\%, lo que significa que el negocio podía ser rentable. 3) El tercer acuerdo del contrato de los seis socios estipuló que también pertenecían a La Escoba "todo el espacio que ocupan las actuales casitas de teja que están al frente de la propia fábrica construidas con fondos de ella, cuya dimensión además de la espresada [sic]; [aclara que] tiene el espacio referido ciento treinta ocho varas $[115.64 \mathrm{~m}]$ por un costado, consta sesenta varas tres cuartas [52.79 m por el otro costado] y por el otro quince varas siete ochavas $[12.57 \mathrm{~m}]$ ". ${ }^{13} \mathrm{O}$ sea, el espacio habitacional había crecido más allá del fabril original. 4) A Manuel Olazagarre se le prohibió establecer cualquier otro negocio en los terrenos que permanecían bajo su propiedad y que eran vecinos a la fábrica; además la sociedad se otorgó la prioridad de compra si éste quisiera venderlos.

Pasaron los años y la fábrica continuó creciendo; según Federico de la Torre, ${ }^{14}$ con el tiempo la propiedad pasó mayoritariamente a la

${ }^{13}$ Idem, f. 71. Las conversiones a metros están basadas en Diccionario..., Cecilio A. Robelo, op. cit.

${ }^{14}$ Federico de la Torre, El patrimonio industrial jalisciense del siglo XIX: entre fábricas de textiles, de papel y de fierro, Secretaría de Cultura, Gobierno de Jalisco, 2007, 82. 
compañía de comercio compuesta por Manuel Olazagarre y Sótero Prieto y con el fallecimiento del primero a comienzos de 1858, fue necesario vender la fábrica que fue comprada en $\$ 460,000^{15}$ por Manuel Escandón, uno de los capitalistas fundadores de la misma. Si comparamos las cifras observaremos que en catorce años la fábrica duplicó su valor, sin embargo, una mínima crítica histórica del documento hace desconfiar de la cifra; desgraciadamente no dispongo de ningún otro documento que pueda aclarar el verdadero valor que pudo tener realmente la fábrica, sobre todo, porque las cifras posteriores que fijan las transacciones que siguen son bastante inferiores.

Con la información de Federico de la Torre, ${ }^{16}$ en 1866 Manuel Escandón vendió la fábrica a Barron y Forbes y Cía.; según Sergio Valerio en 1877, "aparecen como dueños de La Escoba los señores Fernández del Valle Hermanos, con un capital total de \$205,000”, 17 quienes la compraron a sus anteriores dueños. Pero, en 1878, los Fernández del Valle venden $40 \%$ de la fábrica de hilados y tejidos a Guillermo Barron en $\$ 60,000$ por razones que no están señaladas en el protocolo que formaliza esta transacción. ${ }^{18}$ Manuel Fernández del Valle se reservó el derecho de administrar y tomar las decisiones económicas que fuesen necesarias para el buen funcionamiento de la fábrica, en su calidad de propietario mayoritario de $60 \%$ restante. En 1883:

Manuel Fernández del Valle recobró a título de compra, la parte de la fábrica vendida al señor Barron; con ello, Manuel quedó como dueño exclusivo de esa propiedad. Pero seis años después, el 10 de diciembre de 1889 el señor Fernández del Valle la volvió a vender. Esta vez los compradores fueron Viuda e Hijos de Corcuera, Somellera Hermanos, Gonzalo y Modesto Ancira, Fortoul y Chapuy y Gas y Cogordan, la venta fue solo de la mitad proindiviso de la fábrica de Río Blanco y de La Escoba. ${ }^{19}$

${ }^{15}$ AHJ, Protocolo de Juan Riestra, Vol. 14, 06/05/1859, ff. 129v-134. Este documento es la testamentaría de Manuel de Jesús Olazagarre.

${ }^{16}$ Federico de la Torre, ibid.

${ }^{17}$ Sergio Valerio Ulloa, Empresarios extranjeros en Guadalajara durante el porfiriato, Universidad de Guadalajara, Guadalajara, 2002, 105.

${ }^{18}$ AHJ, Protocolo de Heraclio Garcíadiego, vol. 9 12/10/1878, ff. 155-159v.

${ }^{19}$ Sergio Valerio Ulloa, op. cit., pp. 107-108. 
Esta última transacción corresponde al primer intento de agrupar las fábricas textiles y de papel bajo la Compañía Industrial de Jalisco (1889) con un millón de pesos como capital total, con los socios ya nombrados más la firma Moreno Hermanos. ${ }^{20}$ Sin embargo, esta propuesta fue absolutamente fallida pues se disolvió en 1891.

En este último año Fernández del Valle Hermanos, Gas y Cogordan Cía., Fortoul y Chapuy Cía. y Moreno Hermanos quedan como propietarios de Atemajac, La Escoba y Río Blanco y forman una nueva sociedad que otorga a los primeros la administración de las actividades de las tres entidades con un pago de $4 \%$ de las utilidades que se obtuvieran. Las tres fábricas "se dedicarán al ramo de hilados y tejidos de algodón, fabricando en ellas, ya mantas para vender, ya para blanquear o para estampar si llegan a establecerse estos ramos"; ${ }^{21}$ Gas y Cogordan Cía., Fortoul y Chapuy Cía. y Moreno Hermanos quedaron obligados a "consumir las manufacturas de éstas [las fábricas mencionadas] a los precios a que se vendan a los marchantes más favorecidos de la plaza, abonándoseles un descuento de cuatro por ciento sobre lo que realicen". ${ }^{22}$ La proporción de los capitales aportados fue la siguiente: Moreno Hermanos 50\%, Fernández del Valle Hnos. 34.9\%, Gas y Cogordan Cía. y Fortoul y Chapuy Cía $7.5 \%$ cada una. ${ }^{23}$

En julio de 1897, Fernández del Valle Hermanos, Fortoul Chapuy y Cía., L. Gas y Cía., Moreno Hermanos y Sánchez Leñero de manera aún no oficial permutan la fábrica La Escoba, un potrero pegado a ésta en Tesistán y la fábrica Río Blanco con Francisco Martínez Negrete e Hijos quienes a cambio entregan la hacienda San Francisco y Santa Ana ubicadas en Tizapán El Alto (sureste de Jalisco), esta operación la oficializan ante notario en mayo de 1898 y en la cual de común acuerdo evalúan los bienes que se permutan en $\$ 174,389 .{ }^{24}$

${ }^{20}$ Sergio Valerio Ulloa, op. cit., p. 108.

${ }^{21}$ AHJ, Protocolo de Heraclio Garcíadiego, 14/03/1891, vol. 51, f. 162v.

${ }^{22}$ AHJ, Heraclio Garcíadiego, 14/03/1891, vol. 51, f. $163 \mathrm{v}$.

${ }^{23}$ AHJ, Heraclio Garcíadiego, 14/03/1891, vol. 51, f. 165v.

${ }^{24}$ AHJ, José Verea, Protocolo de 12/05/1898, fs. 12 a 27. Lo que sigue de la narración está realizada con base en este mismo documento. 
Fernández del Valle, Augusto Bec y Antonio Gas que actuaron como representantes, entregan todo cuanto existe en las fábricas, edificios, patios, maquinarias, jardines, agua, mercancías, herramientas, talleres, carros, carretas, etcétera, créditos de las fábricas, cuentas activas de tienda, en fin, todo. Francisco Martínez Negrete transfiere la propiedad de las haciendas que comprendían además de las tierras, fábricas de vino, maquinaria, trojes, cercas, plantíos, semillas, magueyeras, árboles, muebles de casa, en resumen todo sin exceptuar nada. ${ }^{25} \mathrm{O}$ sea, en 1901, la fábrica La Escoba pertenecía a Francisco Martínez Negrete e Hijos, los cuales la pierden definitivamente por la quiebra absoluta de sus negocios. Según la documentación judicial del Juzgado de lo Civil del 25 de marzo de 1901, ellos se declaran en suspensión de pagos por falta de liquidez, al respecto, cito textual:

La sociedad mercantil, de carácter colectivo que bajo el expresado nombre ha girado en esta plaza desde el año de 1892, para continuar los negocios de la antigua casa "FRANCISCO MARTÍNEZ NEGRETE", haciéndose cargo del activo y pasivo de ella, se ha visto últimamente en la necesidad de suspender sus pagos, no por falta de valores en general sino especialmente por la de numerario.

Acostumbrados á cumplir religiosamente nuestros compromisos, sin haber faltado nunca a ellos en una larga serie de años, nos ha sido sumamente penoso la expresada suspensión; pero no hemos vacilado en adoptar esa extrema medida, para no causar perjuicios a algunos de nuestros acreedores, como se los habríamos causado si hubiésemos acudido al recurso de enagenar valores para hacernos de dinero y cubrir los créditos más apremiantes. ${ }^{26}$

¿Cuáles fueron las razones de la quiebra? No están de todo claras, pero se pueden lanzar hipótesis que apuntan hacia tres aspectos de la realidad de 1900-1901. Uno, la crisis económica y monetaria que afectó a Jalisco y al país; nos enteramos de ella a través de la lectura de

${ }^{25}$ Idem.

${ }^{26}$ BPJ, Legajos del Inventario de la Quiebra de Francisco Martínez Negrete Alba, Liquidación Judicial, 1901. 
los periódicos ${ }^{27}$ de esos años y de la Gaceta Mercantil ${ }^{28}$ órgano de expresión de la Cámara de Comercio. Dos, la excesiva diversificación de las inversiones pudo ser otra hipotética causa de su fracaso pues a fines de los años noventa del siglo XIX, éstas las vemos en trece empresas distintas entre las que se contaban la Compañía Ferrocarrilera Guadalajara-San Pedro, Río Grande y Banco de Jalisco. ${ }^{29}$ Tres, un sobreendeudamiento e incapacidad de pago a los 107 acreedores a quienes debía un monto de 1,280,130 al momento de la quiebra. ${ }^{30}$

Según el expediente de quiebra, la fábrica La Escoba fue clausurada en 1901 y según Federico de la Torre, en 1902, ésta dejó de funcionar y su maquinaria fue transferida a Atemajac y La Experiencia. ${ }^{31}$

En síntesis, en relación con la propiedad se pueden sacar algunas conclusiones: 1) durante los primeros 37 ańos de vida productiva fue prioritario el capital externo al estado de Jalisco, o sea los socios mayoritarios no vivían en Guadalajara sino en ciudad de México. 2) Los veinticuatro ańos que siguen tuvo como propietarios a conocidos comerciantes-empresarios de origen español y francés. 3) La fábrica tuvo una vida productiva de 62 años, con un impacto considerable en el mercado regional. 4) Quedó un legado arquitectónico significativo en lo que a patrimonio industrial se refiere.

Los datos sobre producción, capacidad tecnológica y número de trabajadores de La Escoba son pocos y muy erráticos, los sintetizo en el cuadro de la página siguiente.

El algodón materia prima para la producción de hilaza y mantas provino los primeros años desde las costas de México, Nueva Orleans y Perú y más tarde desde Colima, Autlán, Tepic y Villa Lerdo. El mercado para la venta de los productos de esta fábrica fue eminentemente regional. ${ }^{32}$ Hay un informe del Administrador de Ren-

${ }^{27}$ BPJ, El Sol, diario de la tarde, 27/12/1900; La Libertad, 28/12/1900 y 26/09/1901.

${ }^{28}$ BPJ, La Gaceta Mercantil, 20/11/1900 y 31/12/1900.

${ }^{29}$ Gladys Lizama Silva, "Francisco Martínez Negrete Alba, 1848-1906: una biografía empresarial tapatía”, Revista $A L H E$, núm. 26, Instituto Mora, 2006.

${ }^{30}$ Legajos del Inventario de la Quiebra de Francisco Martínez Negrete Alba, Liquidación Judicial, 1901, Sección pasivos, fojas s/n.

${ }^{31}$ Federico de la Torre, op. cit., p. 83.

${ }^{32}$ Federico de la Torre, op. cit., p. 80. 
Capacidad técnica y productiva de La Escoba, 1843-1887

\begin{tabular}{|c|c|c|c|c|c|c|c|}
\hline Año & Husos & Telares & Hilaza & Manta & Pabilo & Cordón & $\begin{array}{l}\text { Numero } \\
\text { Traba- } \\
\text { jadores }\end{array}$ \\
\hline $1843 / 44$ & 2,112 & 69 & $\begin{array}{l}21,000 \\
\text { libras } \\
\text { semanales }\end{array}$ & & & & \\
\hline $1854 / 56$ & & & $\begin{array}{l}620,000 \\
\text { libras } \\
\text { anuales }\end{array}$ & $\begin{array}{l}28,000 \\
\text { piezas } \\
\text { anuales }\end{array}$ & & & $809^{*}$ \\
\hline 1875 & 3,000 & 125 & $\begin{array}{l}120,000 \\
\text { libras } \\
\text { anuales }\end{array}$ & $\begin{array}{l}60,000 \\
\text { piezas } \\
\text { anuales }\end{array}$ & $\begin{array}{l}30,000 \\
\text { libras } \\
\text { anuales }\end{array}$ & $\begin{array}{l}1,500 \\
\text { libras } \\
\text { anuales }\end{array}$ & 300 \\
\hline 1879 & & & $\begin{array}{l}798 \text { kilos } \\
\text { por } \\
\text { quincena }\end{array}$ & $\begin{array}{l}4,786 \\
\text { kilos por } \\
\text { quincena }\end{array}$ & $\begin{array}{l}399 \\
\text { kilos por } \\
\text { quincena }\end{array}$ & & \\
\hline 1887 & 3,000 & & & $\begin{array}{l}48,000 \\
\text { piezas } \\
\text { anuales }\end{array}$ & & & 265 \\
\hline
\end{tabular}

Fuente: Elaboración propia con base en Federico de la Torre, El patrimonio industrial jalisciense del siglo XIX: entre fábricas de textiles, de papel y de fierro, p. 80.

* Esta cifra es poco creíble, no obstante es la única de la cual se dispone. No hay estudios que aclaren si años después hubo un proceso de mecanización, por lo tanto, disminuyó el número de trabajadores como se asevera en el cuadro.

tas de Zapopan del 1887 que aclara un poco la situación de la fábrica en ese momento y que cito el fragmento textual:

La Receptoría de Rentas de Zapopan en oficio numero 9, fecha 12 del actual [agosto], me dice lo siguiente: En debida contestación a su nota numero 1389, fecha 31 de mayo próximo pasado, tengo la honra de informar a usted lo siguiente: Conforme con los datos que esta oficina a podido recabar en la fábrica de tejidos denominada la Escoba, los tejidos son de algodón, se abastece de esta materia de Villa Lerdo, San Blas y Autlan; consume anualmente 8,687 qq; su motor son dos ruedas grandes movidas con agua y vapor cuya potencia se calcula de cien caballos; sus usos son 3,000; su producto al año es de 48,000 piezas de manta; emplea para esto 
265 operarios con jornal ordinario de dos y medio reales cada uno ; su valor es de $\$ 150,000$, propiedad de los señores Fernández del Valle Hermanos y sus vías de consumo son Guadalajara y otros puntos inmediatos. ${ }^{33}$

\section{Algunas CONSIDERACIONES SOBRE El INVENTARio}

Está presentado en 47 cuadros cuya ordenación responde a los listados de edificios, maquinaria y contenido de las diferentes secciones: abridor, preparación, hilados, tejidos, engomador, batientes, blanqueo; talleres, bodegas, escritorio, casas, objetos de la capilla, químicos contabilizados en el botiquín, todas las mercancías que se vendían en la tienda, herramientas y existencias de algodón del inventario original de la fábrica La Escoba, realizado por los síndicos de quiebra de la casa Martínez Negrete e Hijos en 1901.

Haré algunos comentarios en relación con ellos sin pretender adentrarme en la historia de la tecnología; por obvias razones requiere de un nivel de especialización del cual carezco, por lo tanto será una presentación breve y sencilla.

En primer lugar aparecen los edificios que alojaron los ocho salones destinados al proceso productivo que nombré más arriba, luego diez bodegas, despacho, cochera y caballerizas y dos pajares, dos cárceles, 91 casas de terrado, 46 casas de bóveda, dos escuelas para niños y niñas, la tienda y la capilla.

Disponía de una maquina de vapor de 80 caballos de fuerza Corliss, dos calderas Babcok \& Wilcox de 90 caballos cada una, una turbina Leffel de 36 caballos y una rueda de veinte pies de diámetro $(5.59 \mathrm{~m})^{34}$ de 25 caballos. Cada salón trae la descripción de la maquinaria en uso y las herramientas, por ejemplo, el de tejidos tenía 154 telares de seis marcas distintas y el de hilados ocho tróciles que disponían de 780 husos para pie y siete tróciles para trama con 882 husos, o sea en total sumaban 1662. También está descrita la cantidad de algodón en elaboración en los salones de cardas, hilados y

${ }^{33}$ AHJ, "Comunicado del Administrador de Rentas de San Pedro al Director de Rentas de Jalisco sobre fábricas, industrias, artes y oficios", Ramo Fomento, F-9-887, Jal/112, núm. 613, f. 12.

${ }^{34}$ Cecilio A. Robelo, Diccionario.., op. cit., s/p. 
tejidos, que suman en total 13.17 toneladas. La capilla presenta los objetos de plata, ornamentos y vestuario, imágenes y óleos y objetos diversos. El botiquín estaba apercibido de 276 productos que iban desde alcohol, cloroformo, jeringas, sulfuro de potasio, atropina, hasta gramos de extracto fluido canabis índica. La tienda es una verdadera caja de sorpresas, vendía de todo: alimentos, vinos, calzado, vestido, abarrotes y miscelánea, mercería, remedios y droguería, papelería, tlapalería y muebles y enseres.

Para especificar un poco más la modernización del proceso productivo de las fábricas textiles de la época cito el siguiente texto:

La mecanización del proceso productivo competía únicamente a la fase del hilado, a través de dos máquinas: la intermitente, llamada mule o mula, que producía un hilo resistente y fino, y la continua de tipo throstle o trócil, que producía un hilo resistente pero más grueso.

Muy pronto debieron sin embargo introducirse otras máquinas que correspondieron a la preparación del hilado (cardas, estiradores y veloces), así como al tejido (telares), pues ya para la década de 1840 los inventarios de algunas fábricas las mencionan. Y aunque no señalan al urdidor, éste debió incorporarse al tiempo que el telar. Para la siguiente década se adoptó el batiente y en la de 1860 el sacudidor, máquinas con las cuales se tenía ya para entonces mecanizada la preparación del hilado. En el decenio de 1870 se introducen máquinas de preparación del tejido (el cańonero y la engomadora); se menciona también la caldera de vapor una máquina para la presentación final de las telas (la dobladora) ${ }^{35}$

La cita anterior sirve muchísimo para aclarar por las evidencias obtenidas en el inventario de la fábrica La Escoba, que estamos frente a un centro productivo moderno de grandes dimensiones que sacaba al mercado hilos y telas. Descrito más detalladamente

${ }^{35}$ Leticia Gamboa, Rosalina Estrada y Josué Villavicencio, "Encuentro con la arqueología de la industria textil del municipio de Puebla en el corredor de Atoyac", en Memorias del primer Congreso mexicano de historia de la ciencia y de la tecnología, Juan José Saldaña, ed., México, Sociedad Mexicana de Historia de la Ciencia y de la Tecnología, 1989, 580. En la documentación encontrada la palabra trócil la escriben con s en vez de c, preferí utilizar la ortografía usada en la actualidad. 
Valor de la fábrica textil La Escoba, 1901

\begin{tabular}{lc}
\hline Ramos o especificaciones & Valor en \$ corrientes \\
\hline Edificios y maquinaria & $206,896.38$ \\
Tres cardas nuevas & $4,915.26$ \\
Salones de blanqueo & $40,000.00$ \\
Existencias en la fábrica & $42,032.54$ \\
118,355 kilogramos de algodón & $69,968.10$ \\
Mantas y telas pendientes de facturarse & $13,327.80$ \\
Hilaza existente & $2,200.00$ \\
Casa y huerta del Cedral & $23,527.00$ \\
Tienda & $15,191.00$ \\
TOTAL & $418,058.08$
\end{tabular}

Fuente: Elaboración propia con base en Legajos del Inventario de la Quiebra de Francisco Martínez Negrete Alba, Liquidación Judicial, 1901, Sección activos, fojas s/n.

éste empezaba con la preparación, esto es, sacudida, batiente y cardado del algodón, luego entraba al estrechador, veloz grueso, veloz intermedio y veloz fino; más adelante el algodón en pabilo entraba a los tróciles, que proporcionaban hilos de pie y de trama para los telares que generaban las telas para enseguida proceder al engomado y doblado.

La Escoba era infinitamente más grande que la fábrica Río Blanco, el valor de los edificios, maquinaria y terrenos de esta última era de $\$ 103,120.61 .^{36}$ Desgraciadamente no hay información fidedigna que permita una comparación con Atemajac o La Experiencia, pero pienso que no iba a la zaga, era una verdadera unidad económica social que albergaba espacios productivos, mercantiles, religiosos,

${ }^{36}$ Véanse al respecto Gladys Lizama Silva, "Inventario fábrica textil Río Blanco, Guadalajara, 1901”, en Letras Históricas, núm. 4, Universidad de Guadalajara, 2011, y Legajos del Inventario de la Quiebra de Francisco Martínez Negrete Alba, Liquidación Judicial, 1901, Sección activos, fojas s/n. 


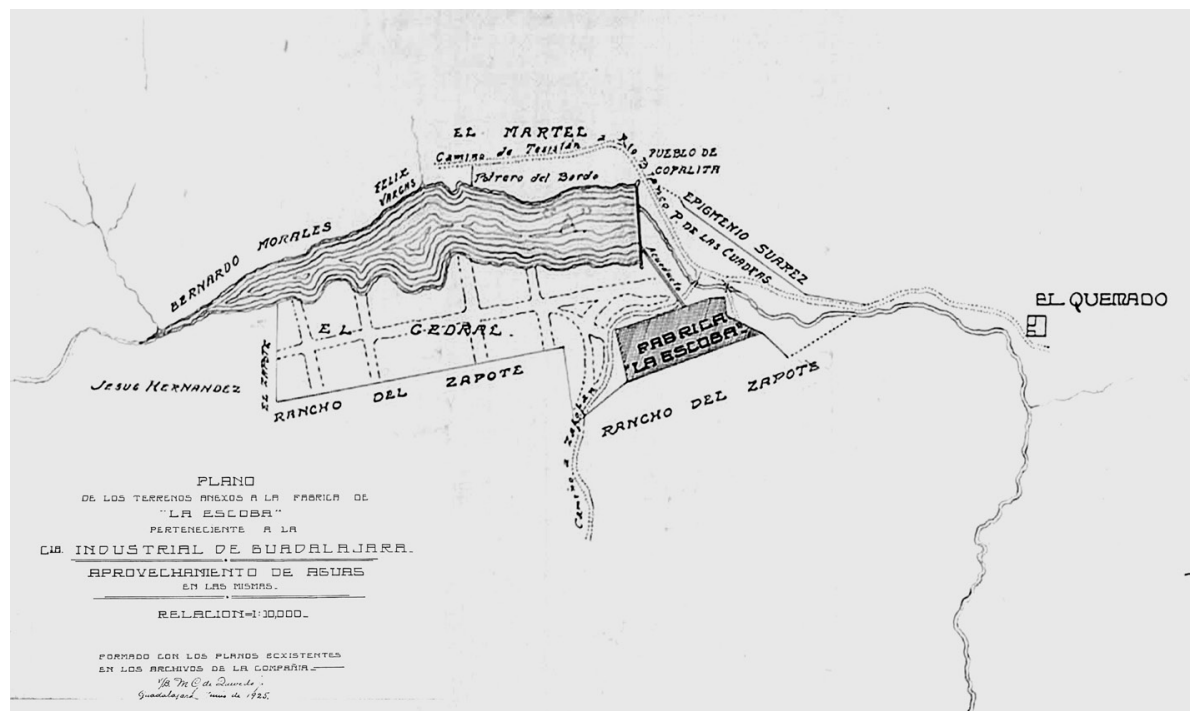

Plano. Detalle del plano de la fábrica La Escoba, Archivo personal de Federico de la Torre.

habitacionales de empleados y obreros, escolares y hasta de control social (cárceles) en su interior. Lamentablemente el inventario no proporciona el valor de cada objeto o producto pero da una idea aproximada de que valía bastante dinero (véase cuadro anterior), por ello cuesta creer que haya sido desmantelada a partir de 1902; si efectivamente fue así puede considerarse una pérdida económica significativa para la industria textil jalisciense del siglo xx.

Para concluir, el inventario de la fábrica La Escoba de 1901, da una idea acabada del nivel de mecanización que poseía, de que sí tenía una pequeña colonia obrera en su interior, de la cantidad de materia prima que disponía en proceso productivo y de los stock de algodón en balas mantenido en bodegas dispuesto para ser procesado y transformado en mercancía textil, además de los espacios administrativos y los talleres de carpintería y herrería. 


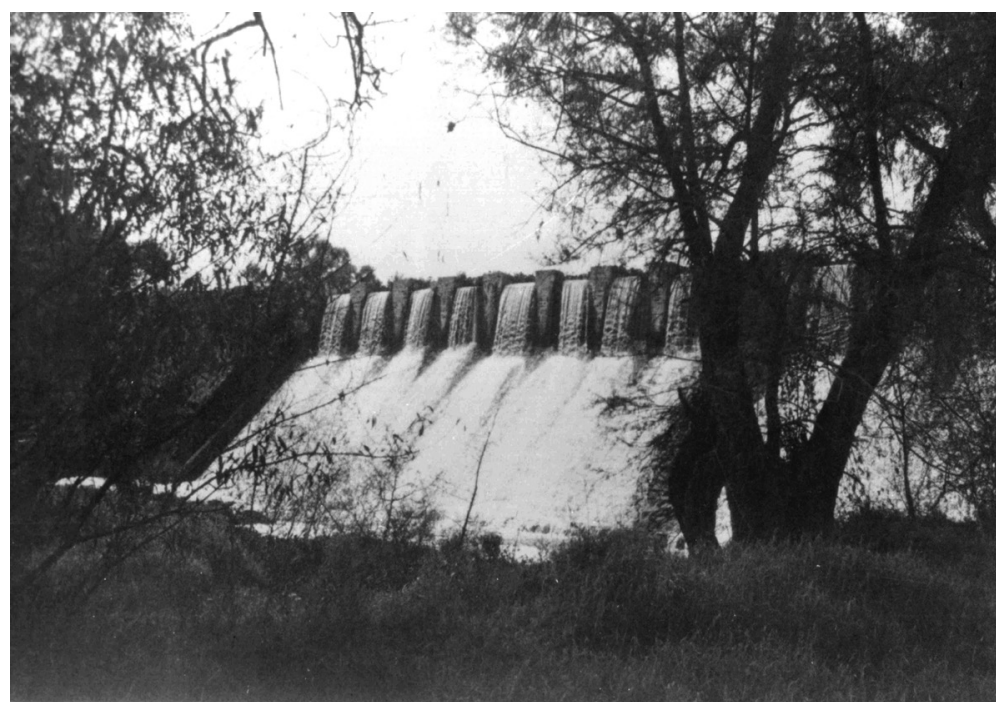

Fото I. Cortina de la presa de La Escoba, Archivo personal de Federico de la Torre.

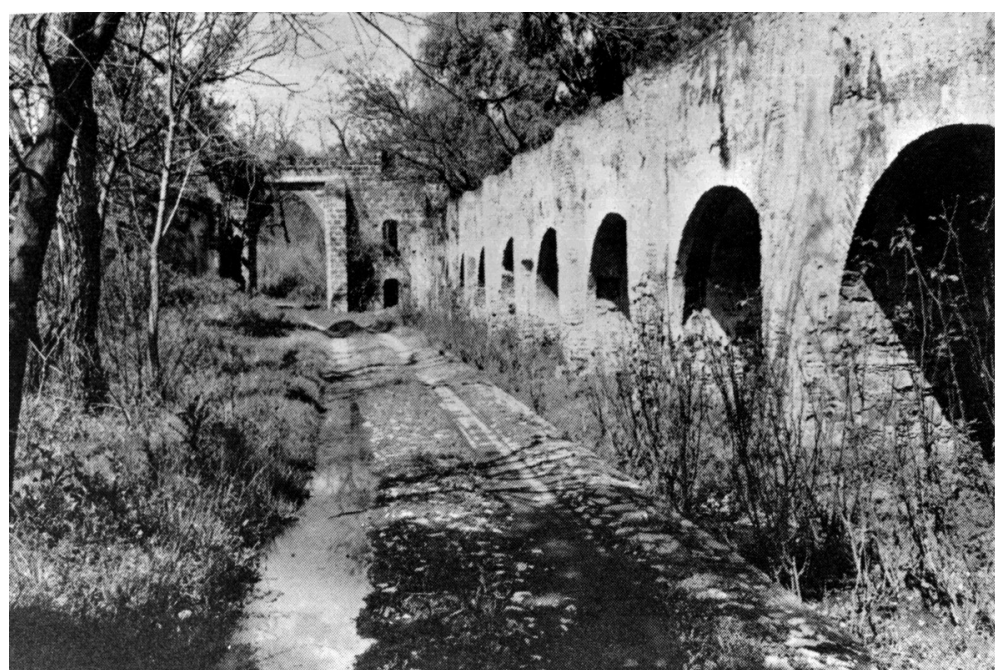

Foto 2. Ruinas del acueducto de La Escoba, Archivo personal de Federico de la Torre. 


\section{Documento}

Inventario de la fábrica textil La Escoba, al momento de la quiebra, 1901

Cuadro 1

PRIMERA SECCIÓN, EDIFICIOS, 1901

\begin{tabular}{ll}
\hline Cantidad & Descripción \\
\hline 1 & Salón del abridor \\
1 & Salón de batientes \\
2 & Salones de preparación \\
2 & Salones de hilado \\
1 & Salón de dobladora \\
2 & Salones de tejidos \\
1 & Salón del engomador \\
1 & Departamento taller para mecánica \\
1 & Departamento carpintería \\
1 & Departamento hojalatería \\
1 & Departamento herrería \\
1 & Salón de blanqueo \\
4 & Bodegas para algodón \\
1 & Bodega para aceite \\
1 & Bodega para cal \\
1 & Bodega para herramientas \\
1 & Bodega para reposiciones \\
1 & Bodega en ruinas \\
1 & Cochera \\
1 & Caballeriza con cuatro departamentos \\
2 & Bodega para mantas con dos departamentos \\
1 &
\end{tabular}


Cuadro 1 (continuación)

PRIMERA SECCIÓN, EDIFICIOS, 1901

\begin{tabular}{cl}
\hline Cantidad & Descripción \\
\hline 1 & Despacho \\
2 & Cárceles \\
1 & Casa de bóveda \\
1 & Casa de terrado \\
89 & Casas de terrado \\
1 & Casa de terrado para el botiquín \\
1 & Casa de calderas \\
45 & Casas de bóveda \\
2 & Escuelas para niños y para niñas \\
1 & Capilla de terrado con dos cruceros \\
\hline
\end{tabular}

Fuente: Inventario Quiebra de Francisco Martínez Negrete, 27 y 28/03/1901, BPEJ, AHSTJ, Ramo Civil, caja 1901-12, Exps. 157180 y 157193 .

\section{Cuadro 2}

PRIMERA SECCIÓN, MAQUINARIA, 1901

\begin{tabular}{cl}
\hline Cantidad & \multicolumn{1}{c}{ Descripción } \\
\hline 1 & Máquina de vapor de 80 caballos "Corliss" \\
1 & Polea de 12.5 pies por 20 pulgadas \\
2 & $\begin{array}{l}\text { Calderas horizontales "Babcok \& Wilcox" de } 90 \text { caballos } \\
\text { cada una }\end{array}$ \\
1 & Turbina "Leffel" horizontal de 36 caballos \\
1 & $\begin{array}{l}\text { Rueda de fierro de } 20 \text { pies de diámetro de } 25 \text { caballos con } \\
\text { 4 piñones y tres chumaceras de fierro }\end{array}$ \\
\hline
\end{tabular}

Fuente: Inventario Quiebra de Francisco Martínez Negrete, 27 y 28/03/1901, BPEJ, AHSTJ, Ramo Civil, caja 1901-12, Exps. 157180 y 157193. 


\section{Cuadro 3}

PRIMERA SECCIÓN, REFACCIONES, 1901

\begin{tabular}{cl}
\hline Cantidad & \multicolumn{1}{c}{ Descripción } \\
\hline 11 & Cabeceras para las calderas \\
32 & Tapones para las calderas \\
35 & Tubos para las calderas \\
6 & Parrillas para las calderas \\
2 & Inyectores para las calderas \\
1 & Manómetro para las calderas \\
1 & Wagon para la leña \\
2 & Carretillas para la leña \\
1 & Pala de fierro \\
1 & Juego de 8 anillos con muelle para la máquina de vapor \\
6 & Llaves \\
2 & Aceiteras \\
2 & Lámparas "Rochester" \\
1 & Lubricador \\
\hline
\end{tabular}

Fuente: Inventario Quiebra de Francisco Martínez Negrete, 27 y 28/03/1901, BPEJ, AHSTJ, Ramo Civil, caja 1901-12, Exps. 157180 y 157193.

\section{Cuadro 4}

SALÓN DE PREPARACIÓN, TRANSMISIONES, 1901

\begin{tabular}{cl}
\hline Cantidad & Descripción \\
\hline 3 & Flechas \\
21 & Pendientes \\
4 & Coplings \\
15 & Poleas diversos tamaños \\
\hline
\end{tabular}

Fuente: Inventario Quiebra de Francisco Martínez Negrete, 27 y 28/03/1901, BPEJ, AHSTJ, Ramo Civil, caja 1901-12, Exps. 157180 y 157193. 
Cuadro 5

\begin{tabular}{cl}
\hline \multicolumn{2}{c}{ SALÓN DE PREPARACIÓN, CONTRA-FLECHA, 1901} \\
\hline Cantidad & Descripción \\
\hline 9 & Flechas \\
41 & Pendientes \\
47 & Poleas de diversos tamaños \\
13 & Coplings \\
5 & Poleas \\
2 & Excéntricas \\
3 & Pendientes de madera \\
\hline
\end{tabular}

Fuente: Inventario Quiebra de Francisco Martínez Negrete, 27 y 28/03/1901, BPEJ, AHSTJ, Ramo Civil, caja 1901-12, Exps. 157180 y 157193.

\section{Cuadro 6}

SALÓN DE PREPARACIÓN, MAQUINARIA, 1901

\begin{tabular}{cl}
\hline Cantidad & \multicolumn{1}{c}{ Descripción } \\
\hline 1 & Abridor sistema "Platt" \\
1 & Batiente sencillo "Lord" de 40 pulgadas \\
1 & Batiente doble "Lord" de 40 pulgadas \\
17 & Cardas de "Platt" \\
3 & Cardas de "Howard \& Bullough" \\
3 & Estrechadores de 3 secciones y 4 entregas cada uno \\
3 & Veloces en grueso, con 60 malacates cada uno \\
1 & Veloz en fino con 128 malacates c/u \\
2 & Intermedios con 104 malacates c/u \\
1 & Máquina para afilar los cilindros de carda \\
1 & Máquina y balanza para las pruebas del pabilo \\
\hline
\end{tabular}

Fuente: Inventario Quiebra de Francisco Martínez Negrete, 27 y 28/03/1901, BPEJ, AHSTJ, Ramo Civil, caja 1901-12, Exps. 157180 y 157193. 
Cuadro 7

\begin{tabular}{|c|c|}
\hline \multicolumn{2}{|c|}{ SALÓN DE PREPARACIÓN, HERRAMIENTAS Y ENSERES, 1901} \\
\hline Cantidad & Descripción \\
\hline 1 & Medidora de pabilo \\
\hline 1 & Balanza \\
\hline 1 & Marco de pesas \\
\hline 1 & Banco con tornillo \\
\hline 1 & Papelera \\
\hline 1 & Armario \\
\hline 1 & Cómoda \\
\hline 337 & Piñones de cambio \\
\hline 28 & Llaves de tuerca \\
\hline 3 & Desarmadores \\
\hline 1 & Tenaza \\
\hline 1 & Escantillón \\
\hline 16 & Aparatos para aceite de coco \\
\hline 5 & Aparatos para petróleo \\
\hline 7 & Faroles \\
\hline 2 & Botes para aceite \\
\hline 8 & Aceiteras \\
\hline 1 & Escalera \\
\hline 4 & Cilindros esmerilados \\
\hline 2 & Limpiadores para cardas \\
\hline 1 & Pulidor para cardas \\
\hline
\end{tabular}

Fuente: Inventario Quiebra de Francisco Martínez Negrete, 27 y 28/03/1901, BPEJ, AHSTJ, Ramo Civil, caja 1901-12, Exps. 157180 y 157193. 
Cuadro 8

SALÓN DE PREPARACIÓN, REFACCIONES, 1901

\begin{tabular}{cl}
\hline Cantidad & Descripción \\
\hline 200 & Botes para estrechador \\
4600 & Cañones grandes \\
800 & Cañones chicos \\
5 & Cintas de esmeril \\
5 & Cintas para limpiador \\
32 & Limpiadores de mano \\
\hline
\end{tabular}

Fuente: Inventario Quiebra de Francisco Martínez Negrete, 27 y 28/03/1901, BPEJ, AHSTJ, Ramo Civil, caja 1901-12, Exps . 157180 y 157193.

Cuadro 9

SALÓN DE HILADOS, MAQUINARIA, 1901

\begin{tabular}{cl}
\hline Cantidad & Descripción \\
\hline 5 & *Trósiles de 280 husos c/u para pié \\
3 & ${ }^{*}$ Trósiles de 500 husos c/u para pié \\
6 & ${ }^{*}$ Trósiles de 300 husos c/u para trama \\
1 & *Trosil de 582 husos para trama \\
1 & Banco para cordoncillo de 64 malacates \\
1 & Máquina para hacer bolas \\
1 & Carretera con 200 malacates \\
3 & Urdidores de varilla \\
1 & Máquina para hacer cordones de trósiles \\
3 & Devanadoras
\end{tabular}




\section{Cuadro 9 (continuación)}

SALÓN DE HILADOS, MAQUINARIA, 1901

\begin{tabular}{cl}
\hline Cantidad & \multicolumn{1}{c}{ Descripción } \\
\hline 1 & Máquina para forrar riolas \\
1 & Máquina para pulir riolas \\
1 & Elevador \\
1 & Bomba \\
2 & Extinguidores "Stempel" \\
1 & Máquina y balanza para las muestras de hilo \\
\hline
\end{tabular}

Fuente: Inventario Quiebra de Francisco Martínez Negrete, 27 y 28/03/1901, BPEJ, AHSTJ, Ramo Civil, caja 1901-12, Exps. 157180 y $157193 .{ }^{*}$ En el inventario está escrito con "s" pero también se escribe Trócil con "c".

\section{Cuadro 10}

SALÓN DE HILADOS, TRANSMISIONES, 1901

\begin{tabular}{cl}
\hline Cantidad & Descripción \\
\hline 14 & Flechas \\
\hline 11 & Coplos \\
39 & Poleas de diversos tamaños \\
61 & Pendientes \\
01 & Pendiente de madera
\end{tabular}

Fuente: Inventario Quiebra de Francisco Martínez Negrete, 27 y 28/03/1901, BPEJ, AHSTJ, Ramo Civil, caja 1901-12, Exps. 157180 y 157193 
Cuadro 11

\begin{tabular}{|c|c|}
\hline \multicolumn{2}{|c|}{ SALÓN DE HILADOS, HERRAMIENTAS Y ENSERES, 1901} \\
\hline Cantidad & Descripción \\
\hline 1 & Cómoda \\
\hline 1 & Aparador \\
\hline 5 & Aceiteras \\
\hline 64 & Chiquigüites \\
\hline 7 & Cajones \\
\hline 2 & Mesas \\
\hline 1 & Medidora para pruebas \\
\hline 1 & Balanza para pruebas \\
\hline 1 & Bascula \\
\hline 1 & Prensa para hilaza \\
\hline 1 & Máquina para hacer riolas \\
\hline 1 & Máquina para pulir riolas \\
\hline 12 & Llaves de tuercas \\
\hline 5 & Llaves de cruz \\
\hline 1 & Martillo \\
\hline 4 & Desatornilladores \\
\hline 4 & Cinceles \\
\hline 1 & Sacabocados \\
\hline 1 & Cepillo de corte \\
\hline 1 & Cepillo de diente \\
\hline 1 & Serrucho de costilla \\
\hline 1 & Formón \\
\hline 1 & Compás de puntas \\
\hline 1 & Tenaza \\
\hline
\end{tabular}




\section{Cuadro 11 (continuación)}

\begin{tabular}{cl}
\hline & SALÓN DE HILADOS, HERRAMIENTAS Y ENSERES, 1901 \\
\hline 1 & Descripción \\
\hline 1 & Escuadra \\
1 & Cuchillo \\
33 & Remachador \\
8 & Aparatos para petróleo \\
3 & Aparatos para aceite \\
17600 & Faroles \\
7370 & Canillas de pié \\
5780 & Canillas de trama grandes \\
\hline
\end{tabular}

Fuente: Inventario Quiebra de Francisco Martínez Negrete, 27 y 28/03/1901, вPEJ, AHSTJ, Ramo Civil, caja 1901-12, Exps. 157180 y 157193.

Cuadro 12

SALÓN DE TEJIDOS, MAQUINARIA, 1901

\begin{tabular}{cl}
\hline Cantidad & Descripción \\
\hline 4 & Telares de "Keihlet" \\
25 & Telares de "Henry" \\
50 & Telares de "Liverey" \\
42 & Telares de "Dugdale" \\
29 & Telares de "W.Mills" \\
2 & Telares de "Robert Hall \& Sons" \\
2 & Telares de "Robert Hall \& Sons" \\
\hline
\end{tabular}

Fuente: Inventario Quiebra de Francisco Martínez Negrete, 25/03/1901. BPEJ. AHSTJ, Ramo Civil, caja 1901-12, Exps. 157180 y 157193. 


\section{Cuadro 13}

SALÓN DE TEJIDOS, TRANSMISIONES, 1901

\begin{tabular}{cl}
\hline Cantidad & \multicolumn{1}{c}{ Descripción } \\
\hline 6 & Flecha \\
4 & Flechas diversos tamaños \\
41 & Coplo \\
48 & Pendientes \\
43 & Pendientes de fierro \\
4 & Pendientes de madera \\
108 & Poleas de diversos tamaños \\
\hline
\end{tabular}

Fuente: Inventario Quiebra de Francisco Martínez Negrete, 27 y 28/03/1901, BPEJ, AHSTJ, Ramo Civil, caja 1901-12, Exps. 157180 y 157193.

\section{Cuadro 14}

SALÓN DE TEJIDOS, HERRAMIENTAS Y ENSERES, 1901

\begin{tabular}{cl}
\hline Cantidad & \multicolumn{1}{c}{ Descripción } \\
\hline 1 & Banco con 2 tornillos \\
15 & Llaves de tuercas \\
4 & Desarmadores \\
11 & Limas \\
3 & Llaves de cruz \\
1 & Formón \\
2 & Tenacillas para peines \\
75 & Chiquigüites \\
51 & Cajones para canilla \\
3 & Bastidores para repasar
\end{tabular}


Cuadro 14 (continuación)

SALÓN DE TEJIDOS, HERRAMIENTAS Y ENSERES, 1901

\begin{tabular}{cl}
\hline Cantidad & Descripción \\
\hline 1 & Bastidor para atar rollos \\
3 & Mesas \\
1 & Banco para rollos \\
1 & Carretilla para rollos \\
30 & Rollos \\
19 & Aparatos para petróleo \\
14 & Aparatos para aceite \\
s/n & Varias aceiteras \\
2 & Botes para aceite \\
1 & Cable Manila \\
\hline
\end{tabular}

Fuente: Inventario Quiebra de Francisco Martínez Negrete, 25/03/1901. вPEJ. AHSTJ, Ramo Civil, caja 1901-12, Exps. 157180 y 157193.

\section{Cuadro 15}

SALÓN DE TEJIDOS, REFACCIONES, 1901

\begin{tabular}{cl}
\hline Cantidad & \multicolumn{1}{c}{ Descripción } \\
\hline 70 & Aviaduras (cta.40) \\
30 & Aviaduras (cta.52) \\
10 & Peines (cta.52) \\
114 & Peines (cta.60) \\
8990 & Canillas chicas en uso \\
4250 & Canillas grandes en uso \\
\hline
\end{tabular}

Fuente: Inventario Quiebra de Francisco Martínez Negrete, 27 y 28/03/1901, BPEJ, AHSTJ, Ramo Civil, caja 1901-12, Exps. 157180 y 157193. 


\section{Cuadro 16}

SALÓN DE TEJIDOS, ENGOMADOR, 1901

\begin{tabular}{cl}
\hline Cantidad & \multicolumn{1}{c}{ Descripción } \\
\hline 1 & Engomador de "Howard \& Bullough" \\
2 & Flecha \\
8 & Pendientes \\
4 & Poleas \\
1 & Coplo \\
1 & Tina grande para fermentos de madera \\
2 & Tinas grandes para fermentos de ladrillo \\
\hline
\end{tabular}

Fuente: Inventario Quiebra de Francisco Martínez Negrete, 27 y 28/03/1901, BPEJ, AHSTJ, Ramo Civil, caja 1901-12, Exps. 157180 y 157193.

\section{Cuadro 17}

SALÓN DE TEJIDOS, CUARTO DE MANTAS, 1901

\begin{tabular}{cl}
\hline Cantidad & Descripción \\
\hline 1 & Flecha \\
4 & Pendientes \\
1 & Coplo \\
5 & Poleas \\
6 & Máquinas para limpiar manta \\
1 & Máquina para doblar manta \\
1 & Balanza con pesas \\
1 & Papelera con banco \\
3 & Mesas para manta \\
2 & Cuchillos \\
2 & Chuzas \\
\hline
\end{tabular}

Fuente: Inventario Quiebra de Francisco Martínez Negrete, 27 y 28/03/1901, BPEJ, AHSTJ, Ramo Civil, caja 1901-12, Exps. 157180 y 157193. 


\section{Cuadro 18}

DEPARTAMENTO DE BLANQUEO, MAQUINARIA, 1901

\begin{tabular}{cl}
\hline Cantidad & \multicolumn{1}{c}{ Descripción } \\
\hline 1 & Caldera de blanquear \\
2 & Pailas grandes para la preparación de las lejías \\
1 & Lavadero grande \\
1 & Lavadero chico \\
1 & Exprimidor sin instalar \\
1 & Bomba sin instalar \\
1 & Tanque de madera forrado de plomo, de 700 litros \\
1 & de capacidad \\
1 & Maquina de aprestar, de dos cilindros \\
2 & Secadora de siete tambores \\
1 & Pailas para la preparación de los aprestos \\
1 & Tórculo de 3 cilindros \\
1 & Cilindro pasta de refacción para el tórculo \\
& Máquina de enrollar y rociar \\
\hline & Máquinas de teñir \\
\hline &
\end{tabular}

Fuente: Inventario Quiebra de Francisco Martínez Negrete, 27 y 28/03/1901, BPEJ, AHSTJ, Ramo Civil, caja 1901-12, Exps. 157180 y 157193. 


\section{Cuadro 19}

\begin{tabular}{cc}
\hline \multicolumn{2}{c}{ DEPARTAMENTO DE BLANQUEO, TRANSMISIONES, 1901} \\
\hline Cantidad & Descripción \\
\hline 3 & Flechas \\
15 & Poleas de diversos tamaños \\
\hline
\end{tabular}

Fuente: Inventario Quiebra de Francisco Martínez Negrete, 27 y 28/03/1901, BPEJ, AHSTJ, Ramo Civil, caja 1901-12, Exps. 157180 y 157193.

\section{Cuadro 20}

\begin{tabular}{ll}
\hline \multicolumn{2}{c}{ DEPARTAMENTO DE BLANQUEO, TELAS EN OPERACIÓN, 1901} \\
\hline Cantidad & Descripción \\
\hline 1160 & Piezas \\
\hline
\end{tabular}

Fuente: Inventario Quiebra de Francisco Martínez Negrete, 27 y 28/03/1901, BPEJ, AHSTJ, Ramo Civil, caja 1901-12, Exps. 157180 y 157193.

\section{Cuadro 21}

DEPARTAMENTO DE BLANQUEO, UTENSILIOS, 1901

\begin{tabular}{cl}
\hline Cantidad & Descripción \\
\hline 18 & Tarimas de madera \\
4 & Mesas \\
5 & Cajas con sus candados \\
2 & Mesas chicas para los rollos \\
4 & Aparatos \\
1 & Maquina de hilvanar de piñones \\
1 & Bascula de plataforma y balanzón \\
1 & Cubeta de plomo \\
6 & Cubetas de hoja de lata \\
2 & Sellos para marcar con sus números
\end{tabular}




\section{Cuadro 21 (continuación)}

\begin{tabular}{cl}
\hline & DEPARTAMENTO DE BLANQUEO, UTENSILIOS, 1901 \\
\hline Cantidad & Descripción \\
\hline 2 & Cuchillos \\
3 & Tijeras \\
2 & Cepillos de cerda \\
2 & Brochas de cerda \\
2 & Llaves tornillo \\
1 & Sacabocados \\
1 & Martillo \\
2 & Areómetros "Baumé" \\
4 & Probetas de cristal \\
2 & Medidas de cobre \\
3 & Rectometros para doblar \\
\hline
\end{tabular}

Fuente: Inventario Quiebra de Francisco Martínez Negrete, 27 y 28/03/1901, BPEJ, AHSTJ, Ramo Civil, caja 1901-12, Exps. 157180 y 157193.

\section{Cuadro 22}

DEPARTAMENTO DE BLANQUEO, PRODUCTOS QUÍMICOS, 1901

\begin{tabular}{cl}
\hline Cantidad & \multicolumn{1}{c}{ Descripción } \\
\hline 500 & Kilogramos de ácido sulfúrico \\
3500 & Kilogramos de sosa cáustica \\
375 & Kilogramos de cloruro de cal \\
720 & Kilogramos de caolín \\
1300 & Kilogramos de almidón \\
35 & Kilogramos de colores varios \\
\hline
\end{tabular}

Fuente: Inventario Quiebra de Francisco Martínez Negrete, 27 y 28/03/1901, BPEJ, AHSTJ, Ramo Civil, caja 1901-12, Exps. 157180 y 157193. 


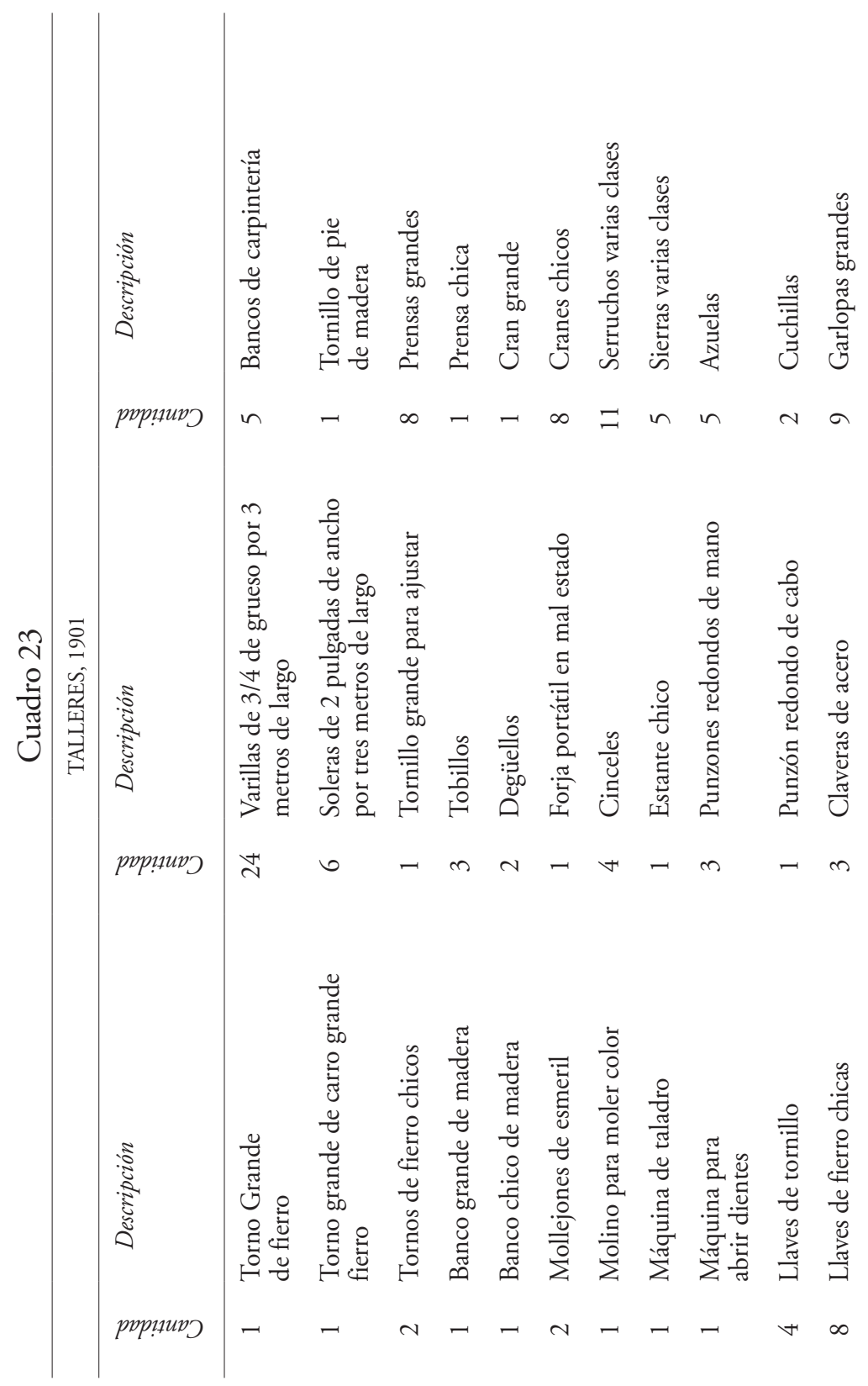




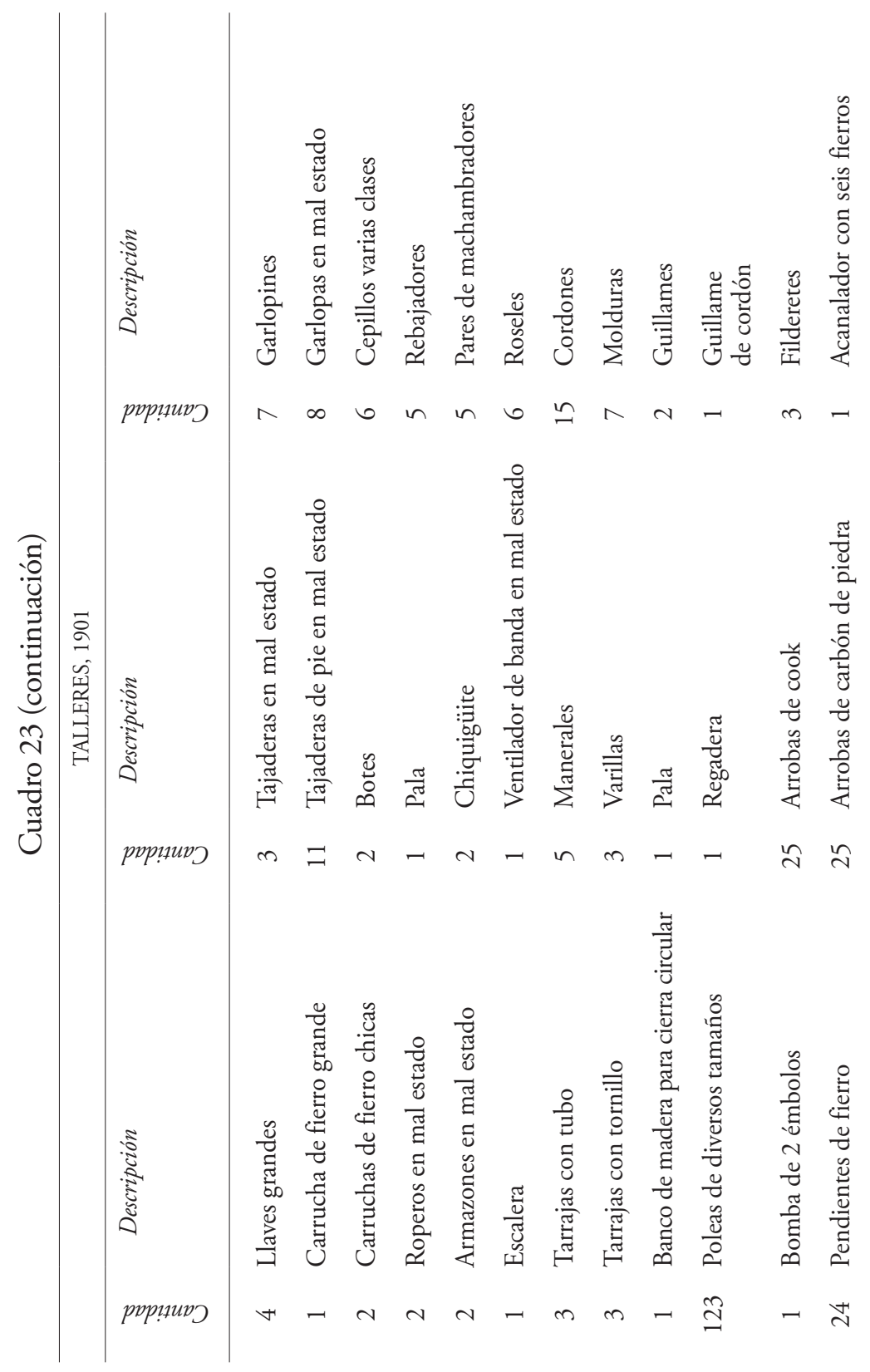



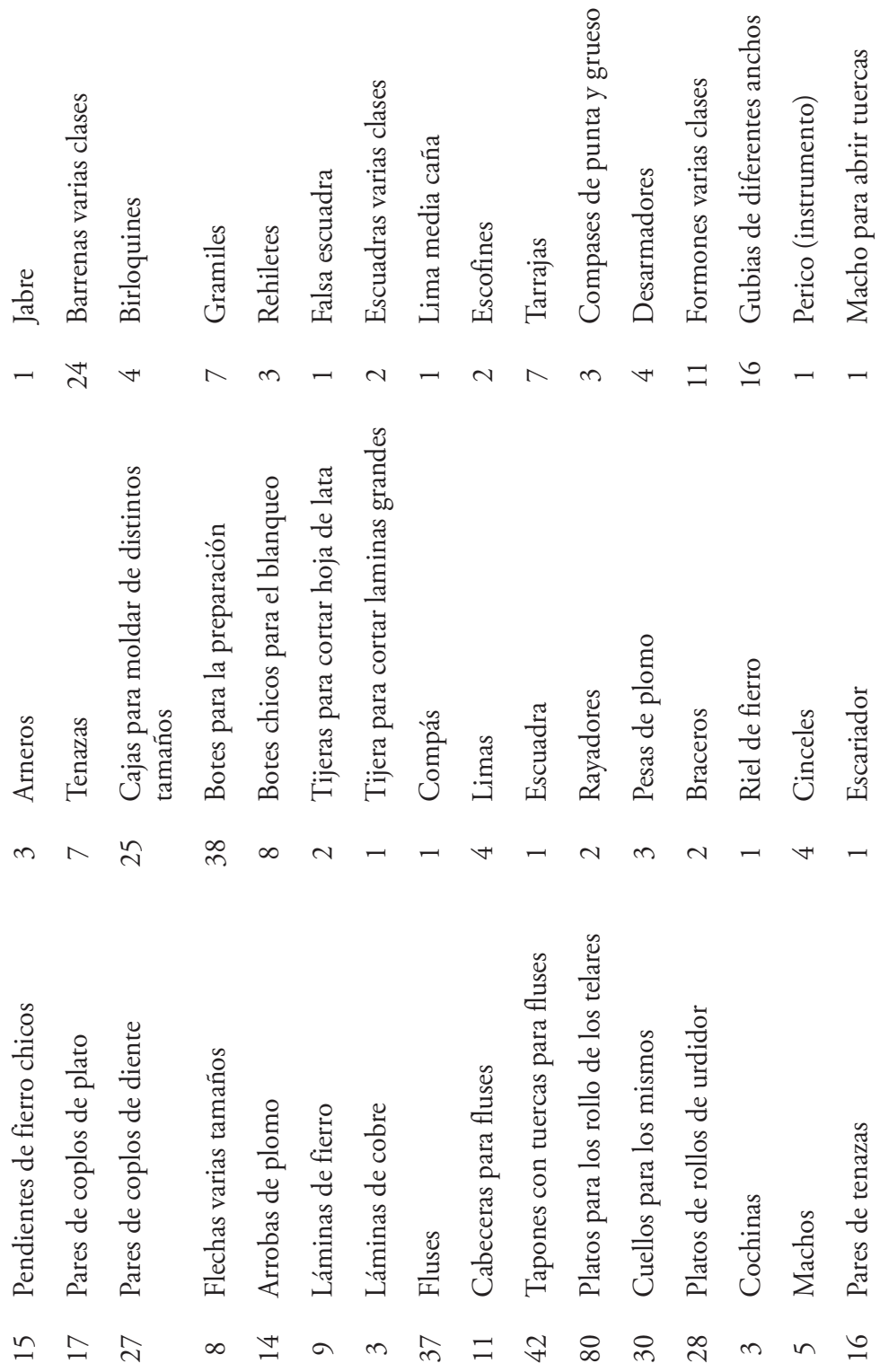


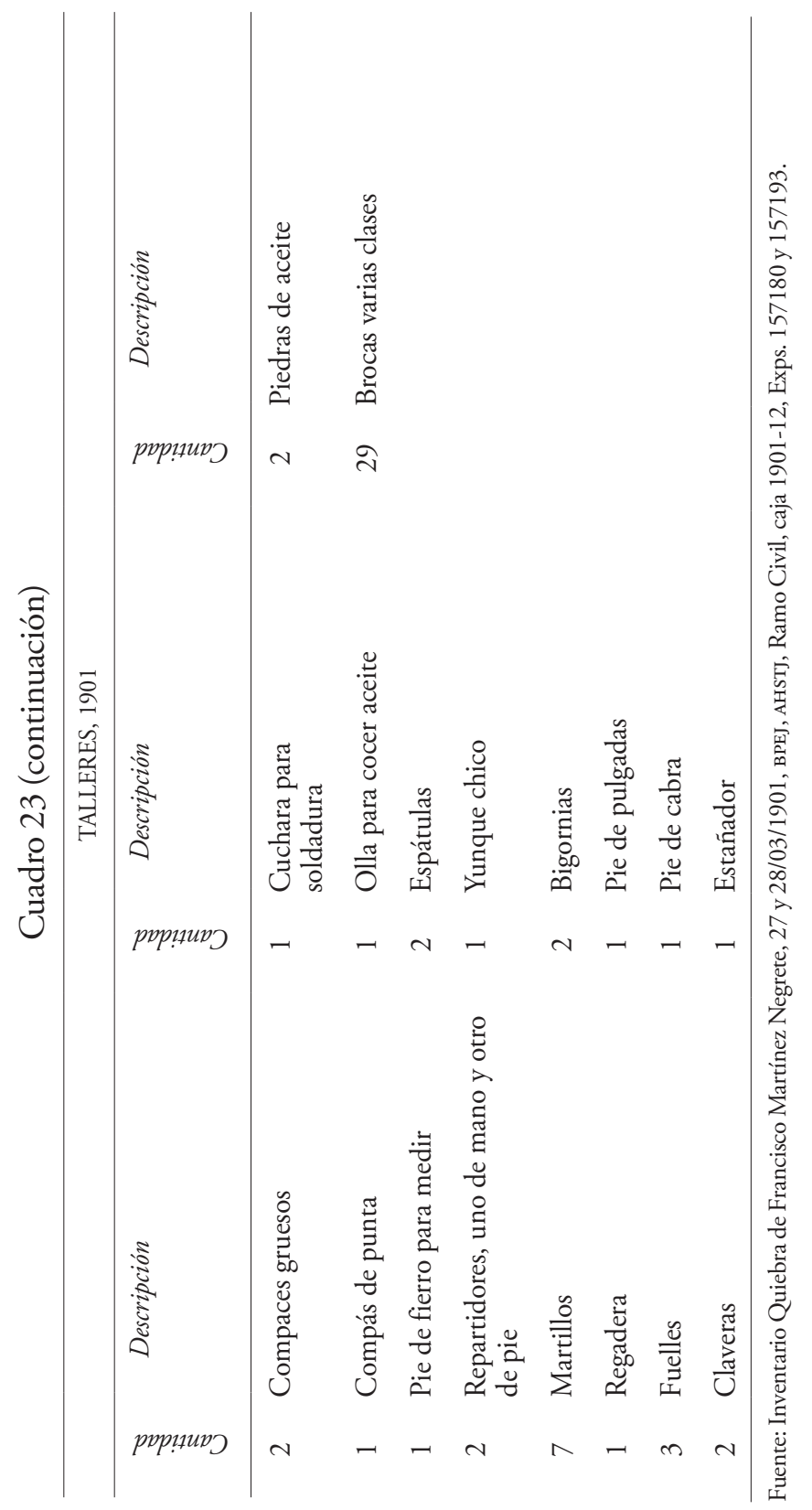




\section{Cuadro 24}

MADERA, 1901

\begin{tabular}{cl}
\hline Cantidad & \multicolumn{1}{c}{ Descripción } \\
\hline 10 & Gualdras en mal estado \\
6 & Vigas de marca en mal estado \\
2 & Vigas de media marca \\
16 & Vigas de encino \\
5 & Cuartones de tepehuaje \\
14 & Tablones de allarin de cinco metros de largo \\
16 & Tablones de allarin de 3 varas de largo \\
3 & Tablas de allarín \\
1 & Timones de roble para ardos \\
6 & Eje de encino para carreta \\
\hline
\end{tabular}

Fuente: Inventario Quiebra de Francisco Martínez Negrete, 27 y 28/03/1901, BPEJ, AHSTJ, Ramo Civil, caja 1901-12, Exps. 157180 y 157193. 


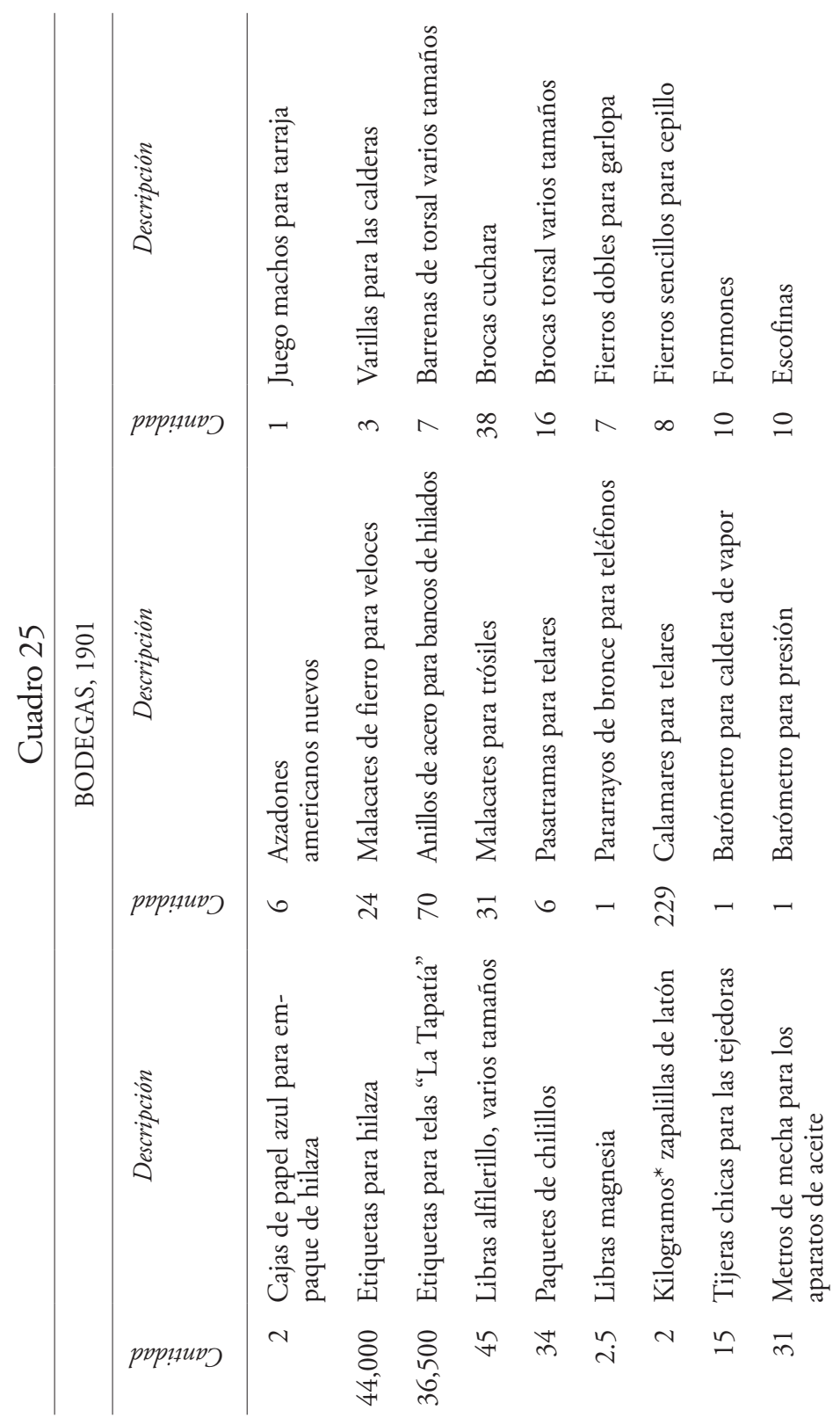




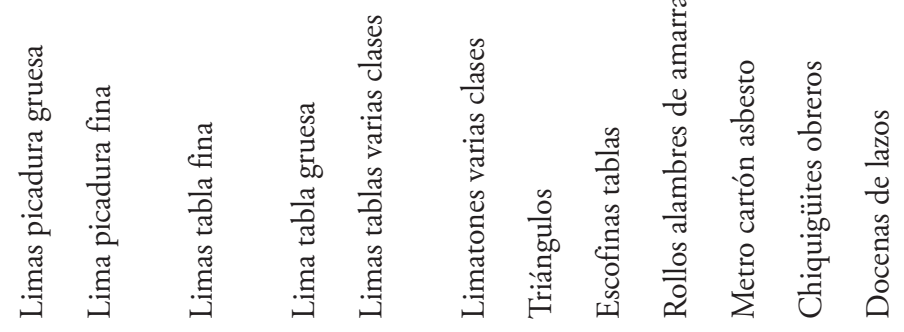

u一 - a d

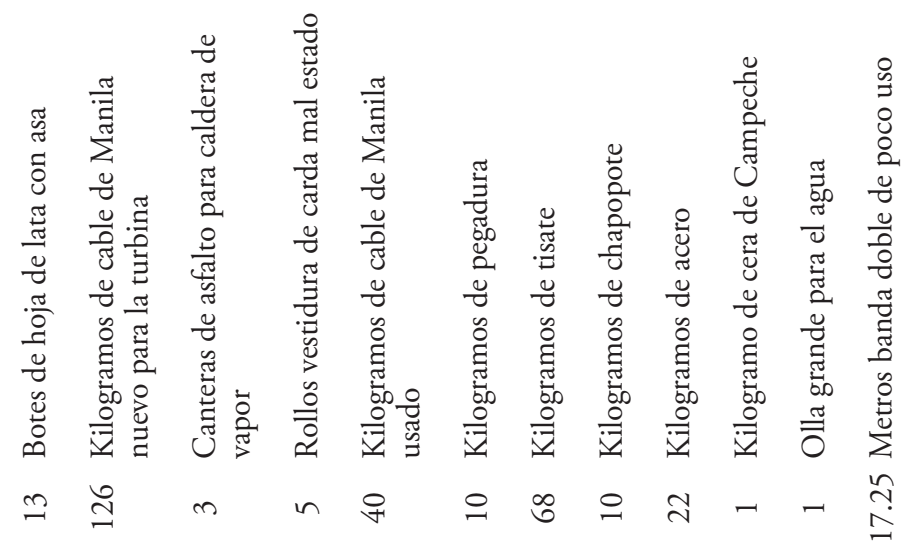

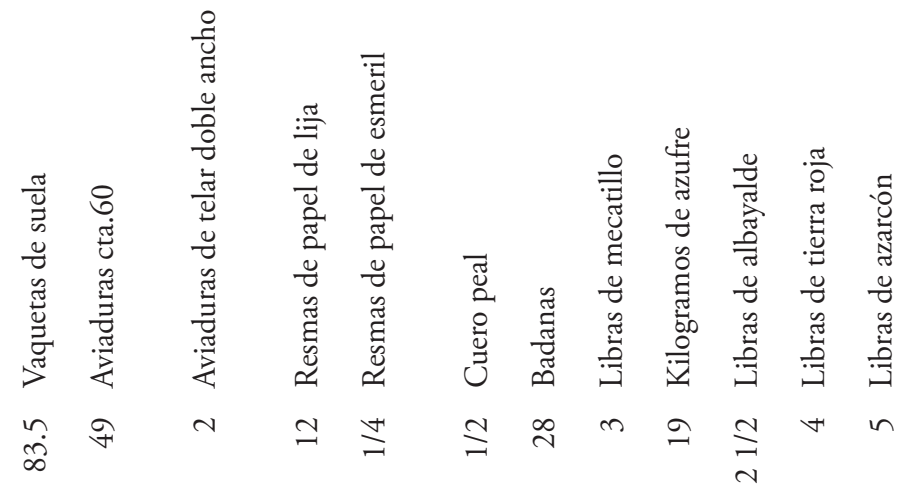




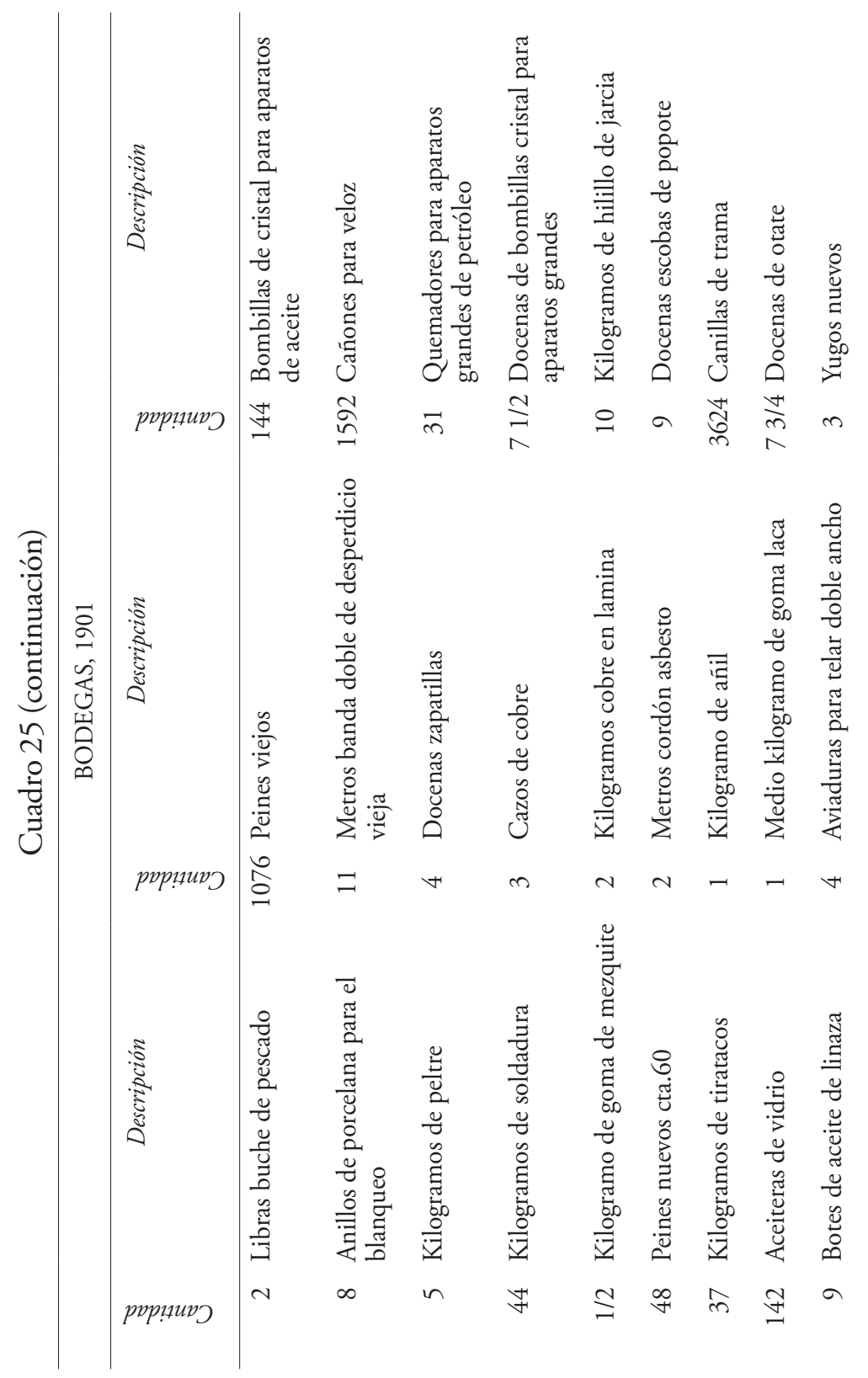



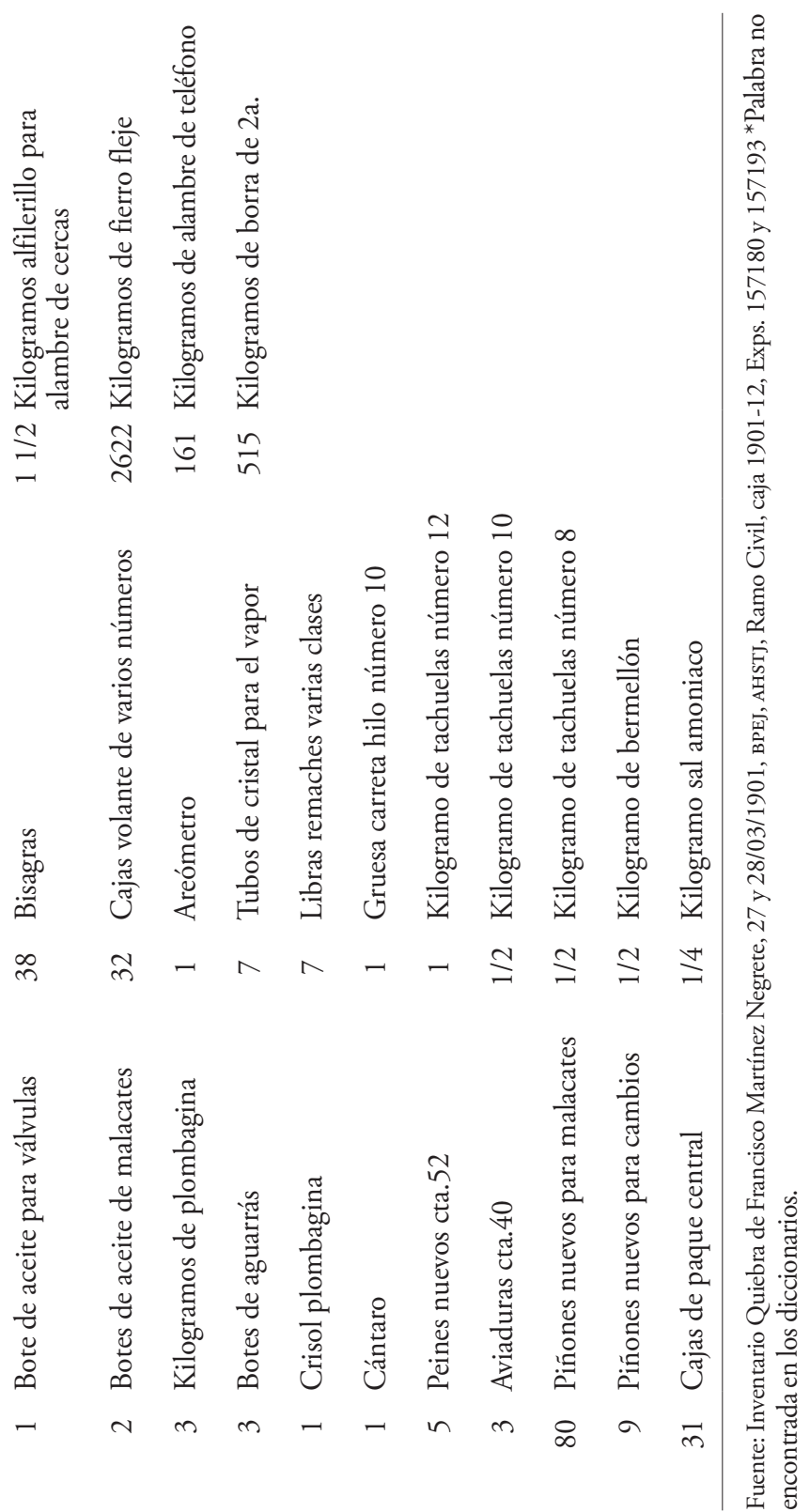


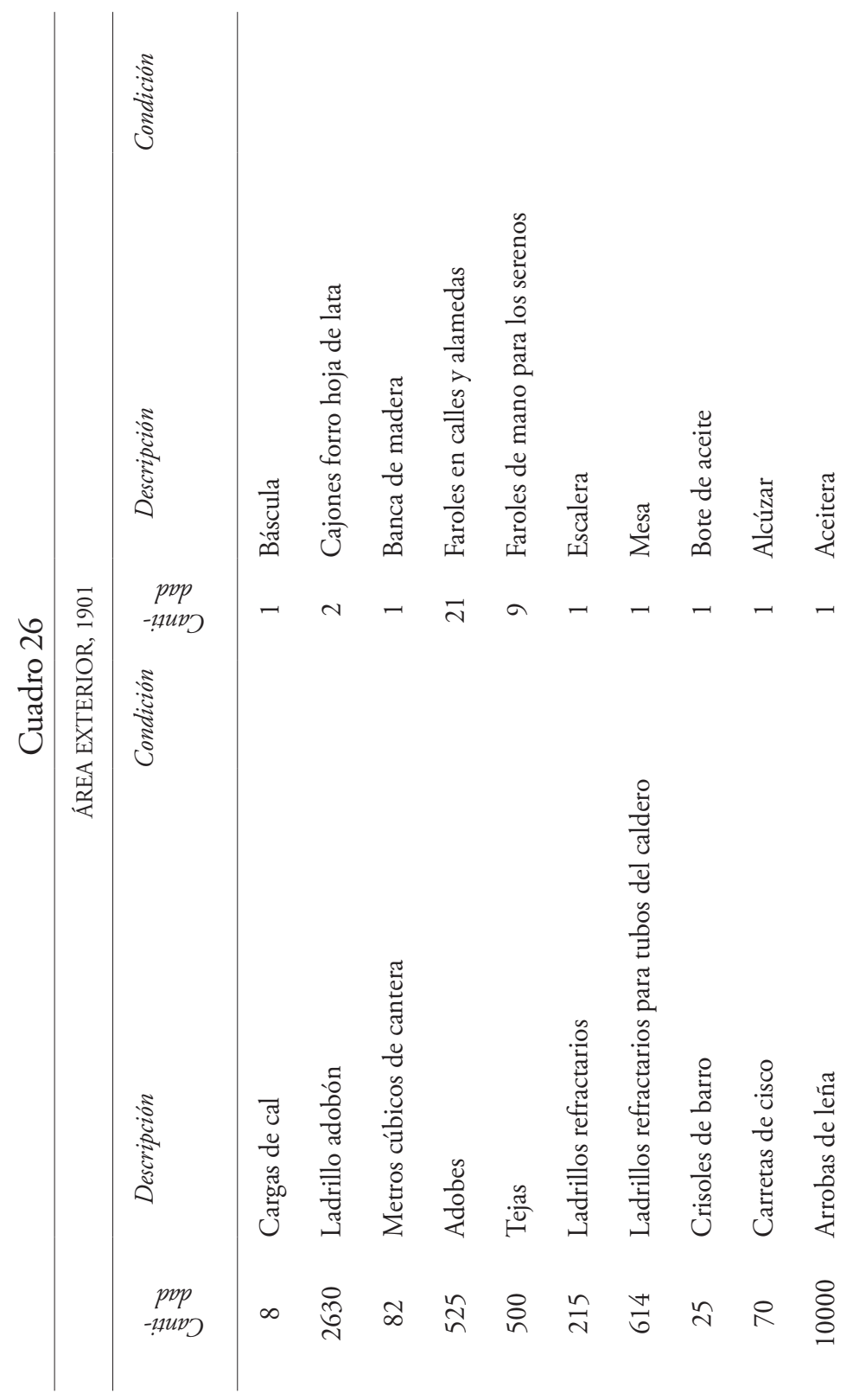



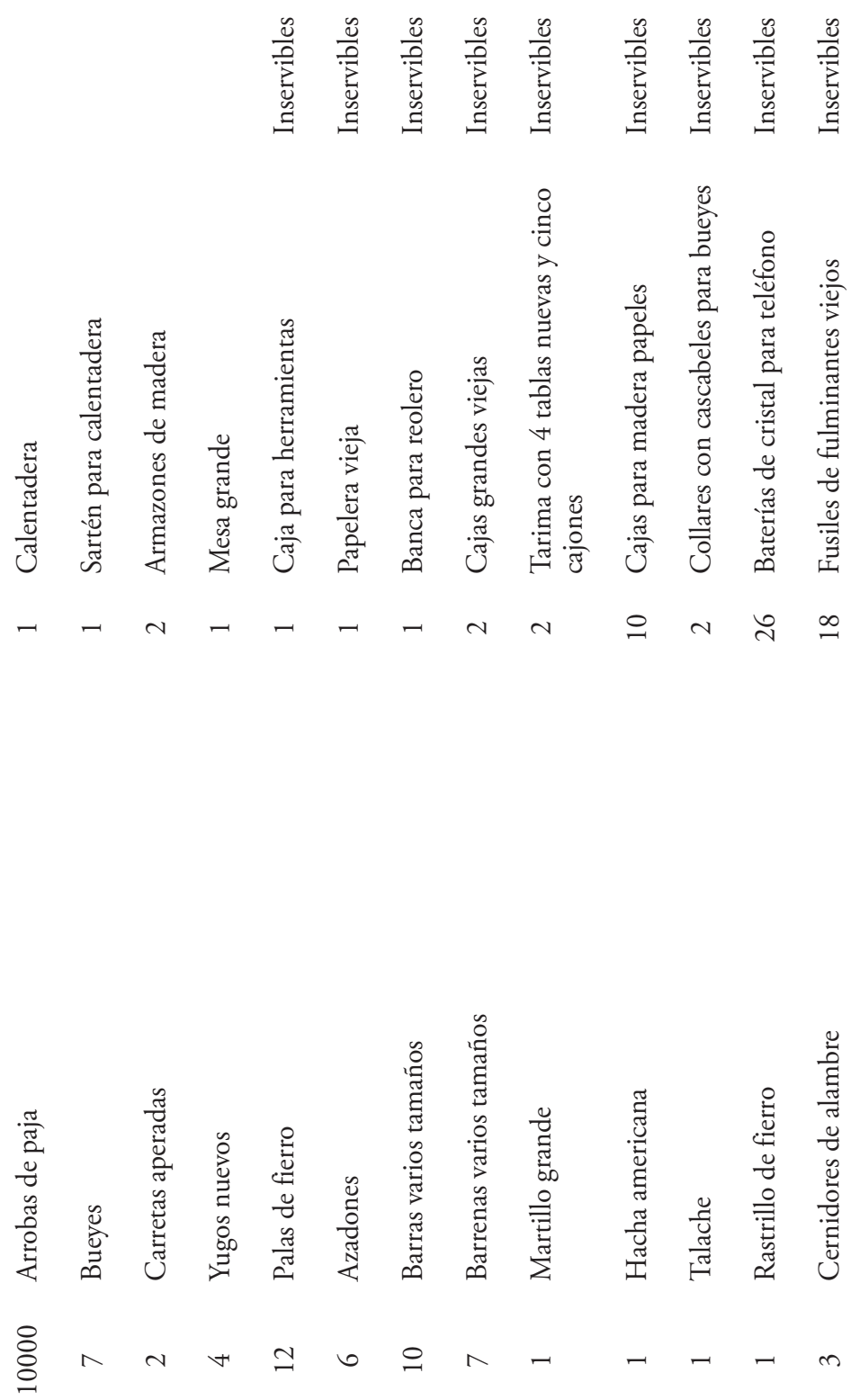


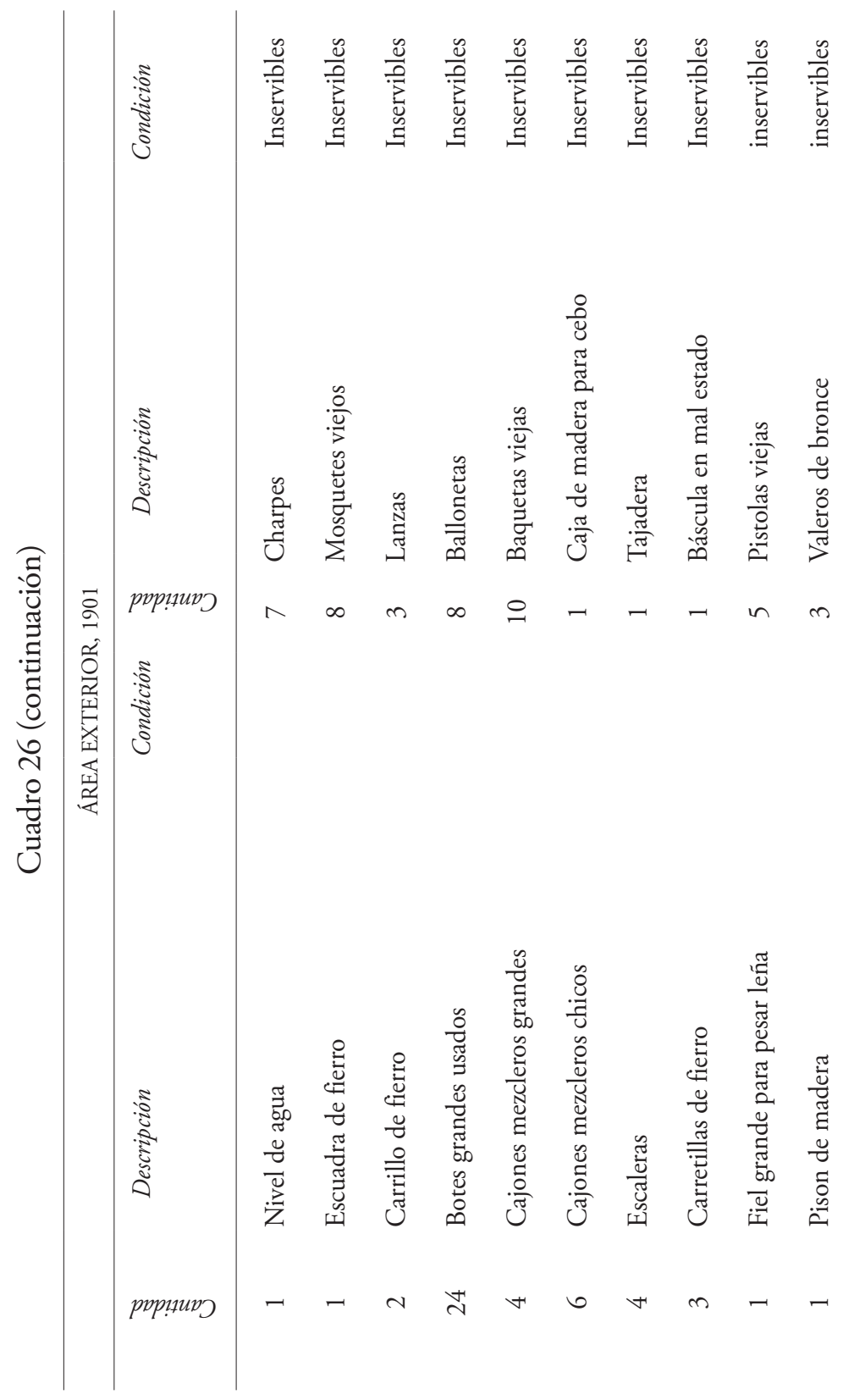




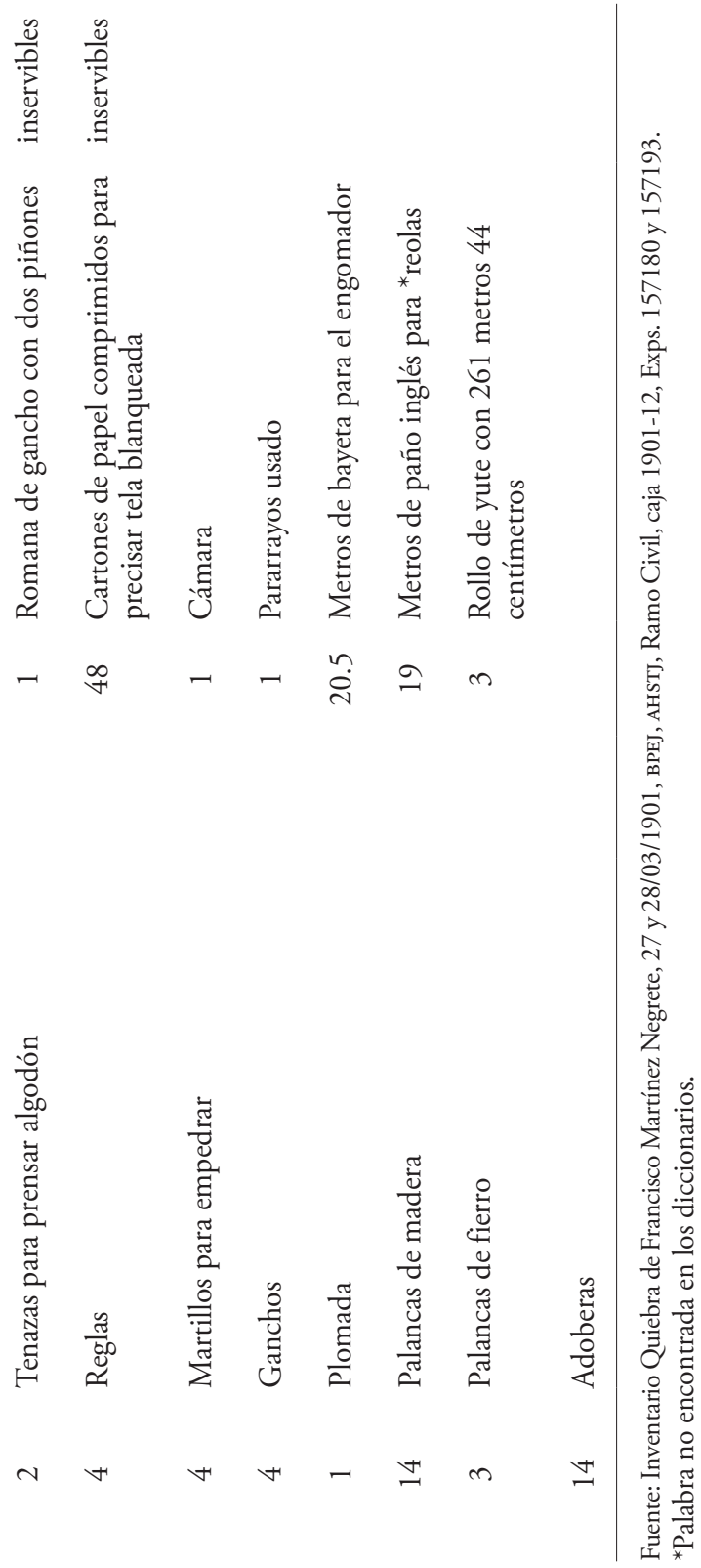


Cuadro 27

ÁREA EXTERIOR, CUARTO DE PRENSA, 1901

\begin{tabular}{cl}
\hline Cantidad & \multicolumn{1}{c}{ Descripción } \\
\hline 1 & Prensa hidráulica para hacer tercios \\
2 & Mostradores de madera \\
1 & Ropero de madera \\
1 & Mesa de alacena \\
1 & Papelera chica para rayar \\
1 & Martillo \\
1 & Cuchillo \\
4 & Agujas \\
4 & Llaves de tuercas \\
1 & Cincel \\
6 & Sellos placas de bronce con la fachada de la \\
2 & fabrica \\
2 & Cajas madera para hacer tercios \\
10 & Armeros de madera \\
1 & Sellos de fierro para tiro de mantas \\
16 & Marca para manta de primera "F.M.N.é H." \\
1 & Letras de bronce para mantas \\
\hline
\end{tabular}

Fuente: Inventario Quiebra de Francisco Martínez Negrete, 27 y 28/03/1901, BPEJ, AHSTJ, Ramo Civil, caja 1901-12, Exps. 157180 y 157193. 
Cuadro 28

ÁREA EXTERIOR, ESCRITORIO, 1901

\begin{tabular}{|c|c|}
\hline Cantidad & Descripción \\
\hline 1 & Caja de fierro \\
\hline 2 & Aparatos telefónicos \\
\hline 4 & Equipales \\
\hline 2 & Mostradores \\
\hline 1 & Papelera grande vieja \\
\hline 1 & Papelera chica \\
\hline 1 & Mesa cómoda \\
\hline 1 & Prensa de fierro para copiar \\
\hline 1 & Aguamanil de fierro con su taza y palangana \\
\hline 1 & Reloj para los serenos con 64 carátulas \\
\hline 2 & Lámparas \\
\hline 1 & Esfera \\
\hline 1 & Banco de madera \\
\hline 1 & Silla de madera \\
\hline 2 & Transparentes \\
\hline 2 & Tinteros \\
\hline 2 & Cantinas de cuero para traer la raya \\
\hline 2 & Planos de las calderas de vapor \\
\hline
\end{tabular}


Cuadro 28 (continuación)

\begin{tabular}{cl}
\hline Cantidad & ÁREA EXTERIOR, ESCRITORIO, 1901 \\
\hline 1 & \multicolumn{1}{c}{ Descripción } \\
\hline 1 & Exprimidor para copiar \\
3 & Carabinas de primera \\
5 & Rifles "Remington con 323 tiros paque central y \\
1 & circular, 8 carrrilleras" \\
1 & Pistola Colts \\
1 & Estante \\
\hline
\end{tabular}

Fuente: Inventario Quiebra de Francisco Martínez Negrete, 27 y 28/03/1901, BPEJ, AHSTJ, Ramo Civil, caja 1901-12, Exps. 157180 y 157193 


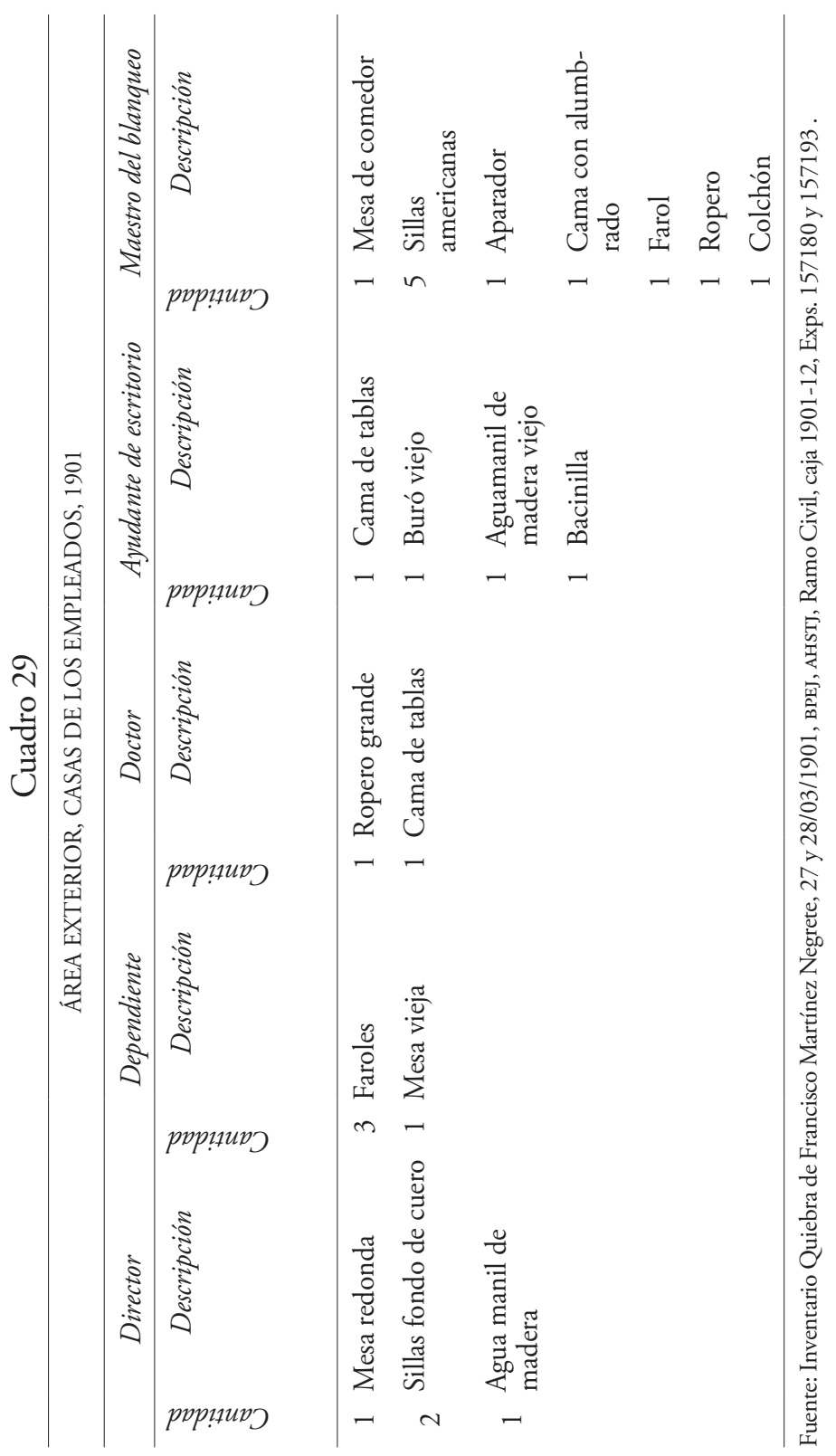




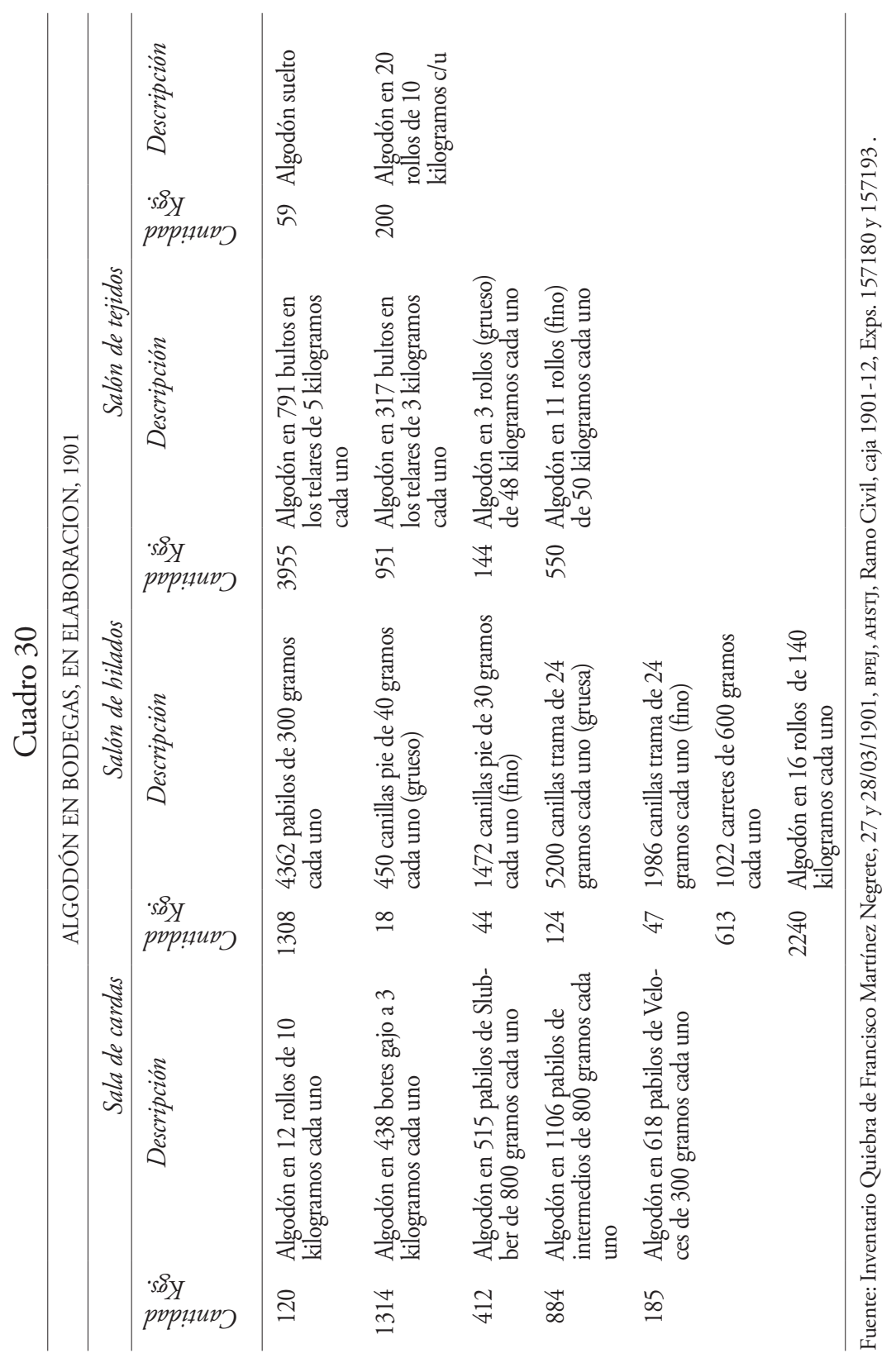


Cuadro 31

ALGODÓN EN BODEGAS, EN BRUTO 1901

\begin{tabular}{ccc}
\hline Cantidad & Medida & Kilogramos \\
\hline 93 & Balas & 24,112 \\
\hline 123 & Balas & 8,642 \\
\hline
\end{tabular}

Fuente: Inventario Quiebra de Francisco Martínez Negrete, 27 y 28/03/1901, BPEJ, AHSTJ, Ramo Civil, caja 1901-12, Exps. 157180 y 157193.

\section{Cuadro 32}

ALGODÓN, BODEGA DE MANTAS, 1901

\begin{tabular}{cl}
\hline Cantidad & Descripción \\
\hline 5 & Tercios de manta de primera \\
10 & Piezas de manta de primera sueltas \\
6 & Tercios de tela cruda \\
23 & Piezas de tela blanqueada \\
3 & Piezas de tela asargada \\
14 & Piezas de tela cruda de desecho \\
1 & Pieza de piqué \\
8 & Bultos retazos de manta para empaque \\
\hline
\end{tabular}

Fuente: Inventario Quiebra de Francisco Martínez Negrete, 27 y 28/03/1901, BPEJ, AHSTJ, Ramo Civil, caja 1901-12, Exps. 157180 y 157193. 
Cuadro 33

CAPILLA, OBJETOS DE PLATA, 1901

\begin{tabular}{cl}
\hline Cantidad & Descripción \\
\hline 2 & Cálices dorados a fuego \\
2 & Copones dorados a fuego \\
1 & Custodia dorada a fuego \\
2 & Ánforas para los Santos Óleos \\
1 & Platillo dorado a fuego \\
\hline
\end{tabular}

Fuente: Inventario Quiebra de Francisco Martínez Negrete, 27 y28/03/1901. BPEJ. AHSTJ, Ramo Civil, caja 1901-12, Exps. 157180 y 157193.

\section{Cuadro 34}

CAPILLA, ORNAMENTOS Y VESTUARIO, 1901

\begin{tabular}{cl}
\hline Cantidad & Descripción \\
\hline 18 & Casullas de todos colores \\
6 & Capas pluviales \\
4 & Albas \\
13 & Amitos \\
2 & Cíngulos diversos colores \\
2 & Velos humerales \\
1 & Dalmáticas \\
2 & Atrilera \\
4 & Frontales de seda \\
6 & Sobrepellices grandes \\
1 & Sobrepellices chicos para los acólitos \\
& Roquete
\end{tabular}


Cuadro 34 (continuación)

\begin{tabular}{cl}
\hline \multicolumn{1}{c}{ CAPILLA, ORNAMENTOS Y VESTUARIO, 1901 } \\
\hline 3 & Descripción \\
\hline 8 & Opas para los acólitos \\
3 & Lienzos de altar \\
1 & Manteles de lino \\
4 & Mantel de seda para el altar mayor \\
6 & Copones \\
4 & Manteles para el comulgatorio \\
8 & Campanas \\
1 & Manteles para los altares pequeños \\
4 & Cobertera de hule para altar \\
2 & Coberteras de lienzo \\
1 & Coberteras para la cómoda de la sacristía \\
8 & Bonete \\
\hline 09 & Corporales \\
\hline & Purificadores \\
\hline &
\end{tabular}

Fuente: Inventario Quiebra de Francisco Martínez Negrete, 27 y 28/03/1901. BPEJ. AHSTJ, Ramo Civil, caja 1901-12, Exps. 157180 y 157193. 


\section{Cuadro 35}

CAPILLA, IMÁGENES Y OLEOS, 1901

\begin{tabular}{cl}
\hline Cantidad & \multicolumn{1}{c}{ Descripción } \\
\hline 1 & Estatua del Sagrado Corazón de Jesús \\
1 & Estatua de Nuestra Señora de Lourdes \\
1 & Estatua de Nuestra Señora de los Dolores \\
1 & Crucifijo de talla tamaño natural \\
4 & Crucifijos de metal \\
2 & Ángeles de madera \\
2 & Pinturas de Nuestra Señora de Guadalupe \\
1 & Pintura de Jesús Crucificado \\
1 & Pintura de la Inmaculada Concepción \\
1 & Pintura del Señor San José \\
2 & Pintura de Nuestra Señora del Refugio \\
& Pinturas que están en las paredes de la capilla \\
\hline
\end{tabular}

Fuente: Inventario Quiebra de Francisco Martínez Negrete 25/03/1901. BPEJ. AHSTJ, Ramo Civil, caja 1901-12, Exps. 157180 y 157193. 
Cuadro 36

CAPILLA, OBJETOS DIVERSOS, 1901

\begin{tabular}{cl}
\hline Cantidad & \multicolumn{1}{c}{ Descripción } \\
\hline 2 & Juegos vinajeras de cristal \\
2 & Altares \\
2 & Mesas de altar \\
2 & Coronas de plata para el Señor San José \\
2 & Alfombras grandes \\
2 & Alfombras chicas \\
3 & Sillones \\
1 & Órgano \\
2 & Templetes \\
1 & Sagrario \\
2 & Confesonarios \\
3 & Escaleras \\
1 & Varipalio \\
1 & Pabellón de seda \\
34 & Columnas de madera \\
12 & Jarrones de Cristal \\
14 & Ramos dorados \\
6 & Ramos de colores \\
1 & Arco dorado para el trono \\
1 & Esfriles \\
3 & \\
16 & Candiles de metal \\
\hline & \\
2 & \\
2 &
\end{tabular}




\section{Cuadro 36 (continuación)}

\begin{tabular}{cl}
\hline & CAPILla, OBJETOS DIVERSOS, 1901 \\
\hline 3 & \multicolumn{1}{c}{ Descripción } \\
\hline 1 & Fanales de cristal \\
1 & Lámpara de metal \\
5 & Bonete \\
2 & Misales \\
1 & Ciriales \\
12 & Cruz alta \\
18 & Candeleros de metal grandes \\
18 & Candeleros de metal medianos \\
\hline
\end{tabular}

Fuente: Inventario Quiebra de Francisco Martínez Negrete, 27 y 28/03/1901. BPEJ. AHSTJ, Ramo Civil, caja 1901-12, Exps. 157180 y 157193. 


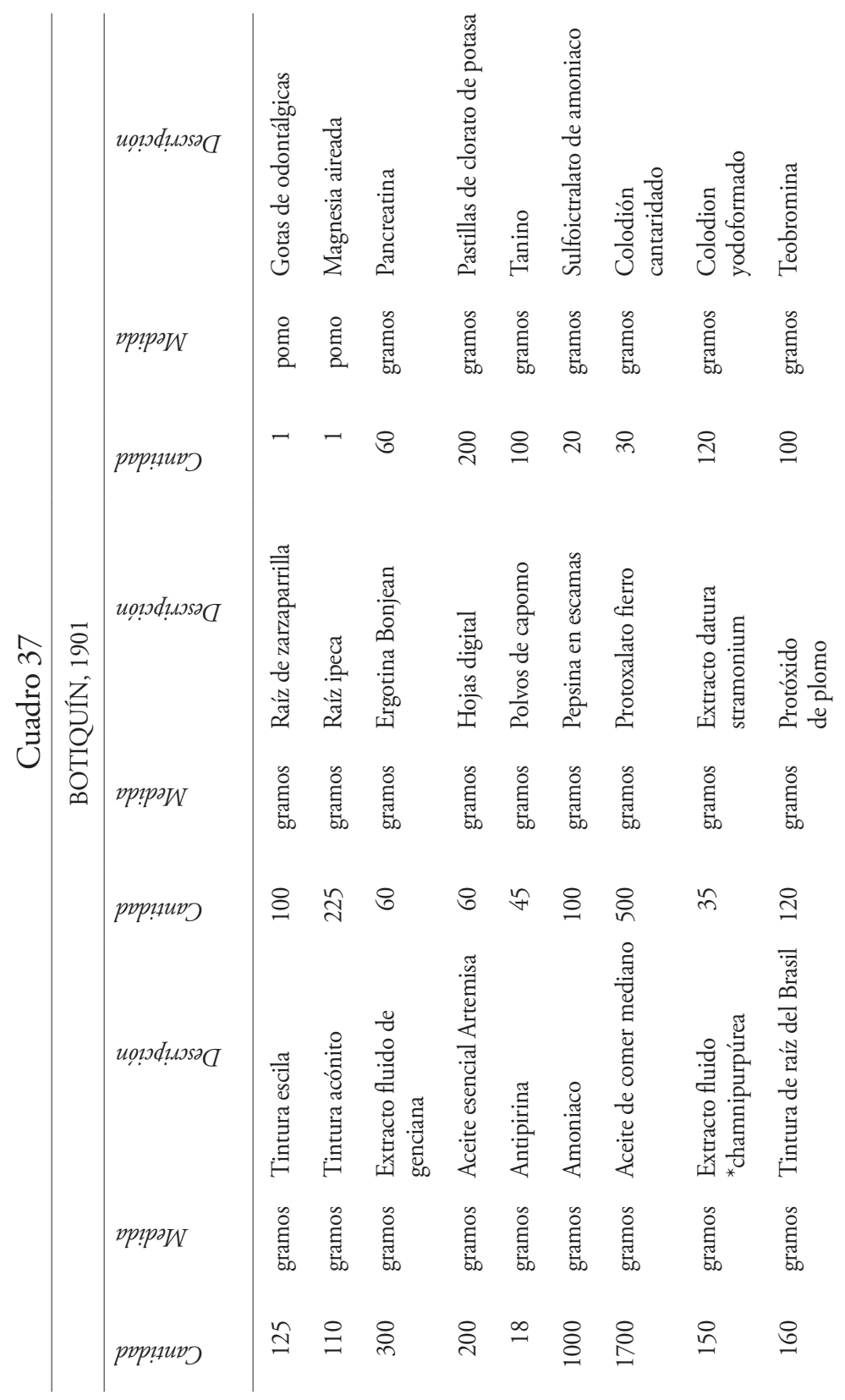




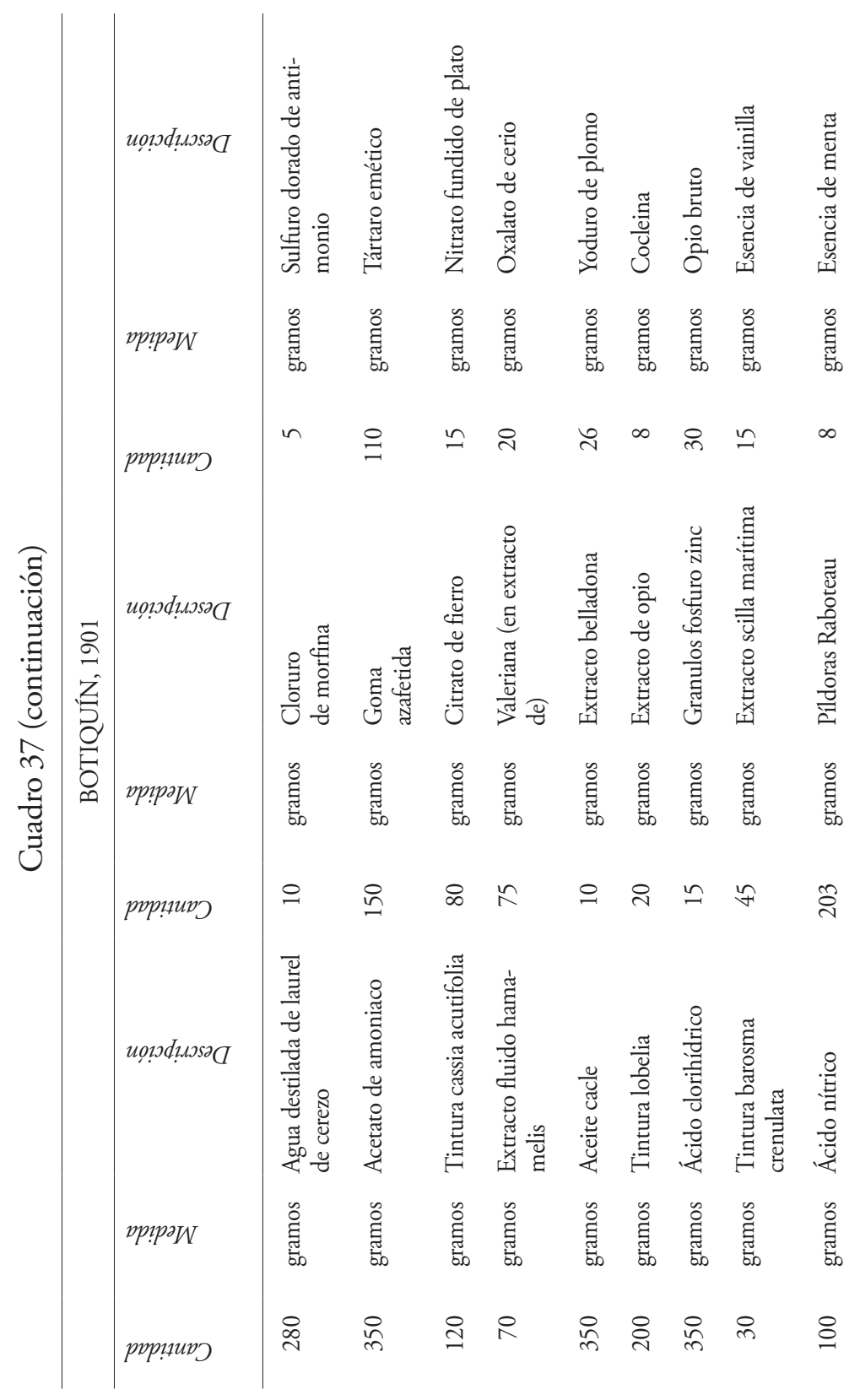




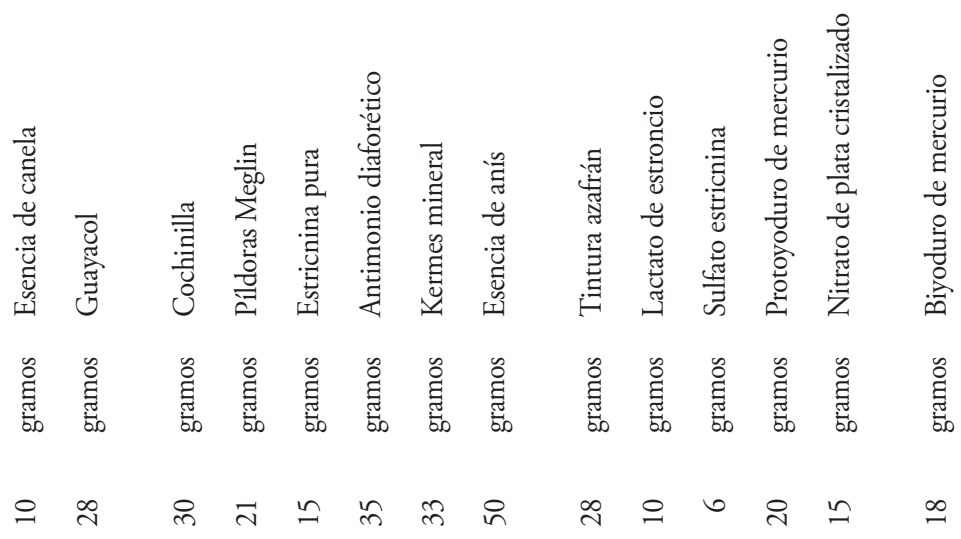

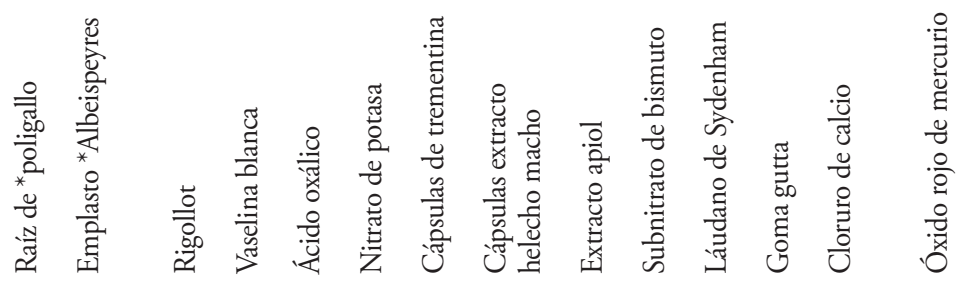

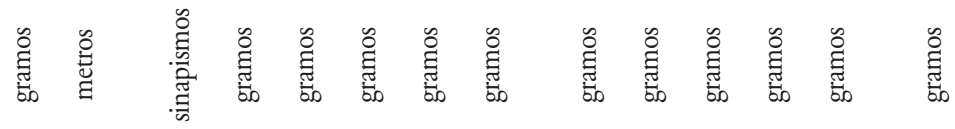

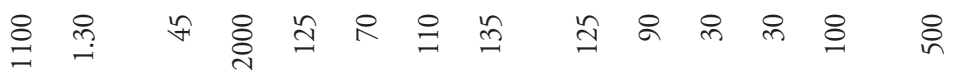

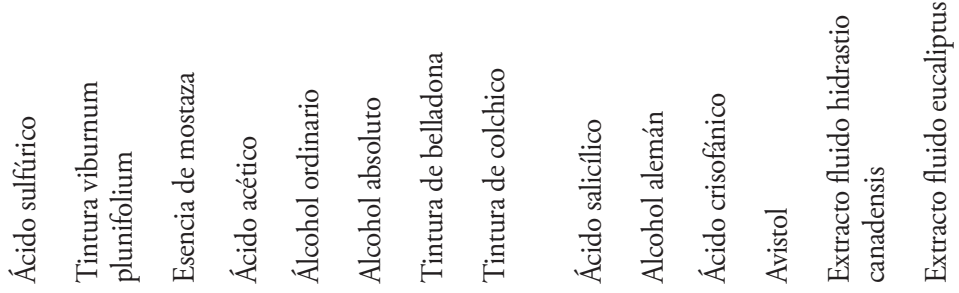

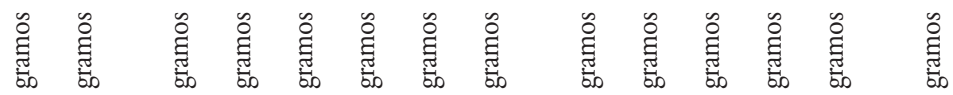

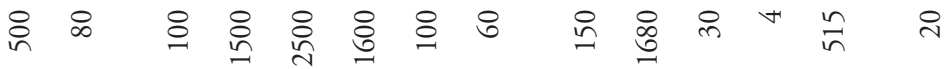




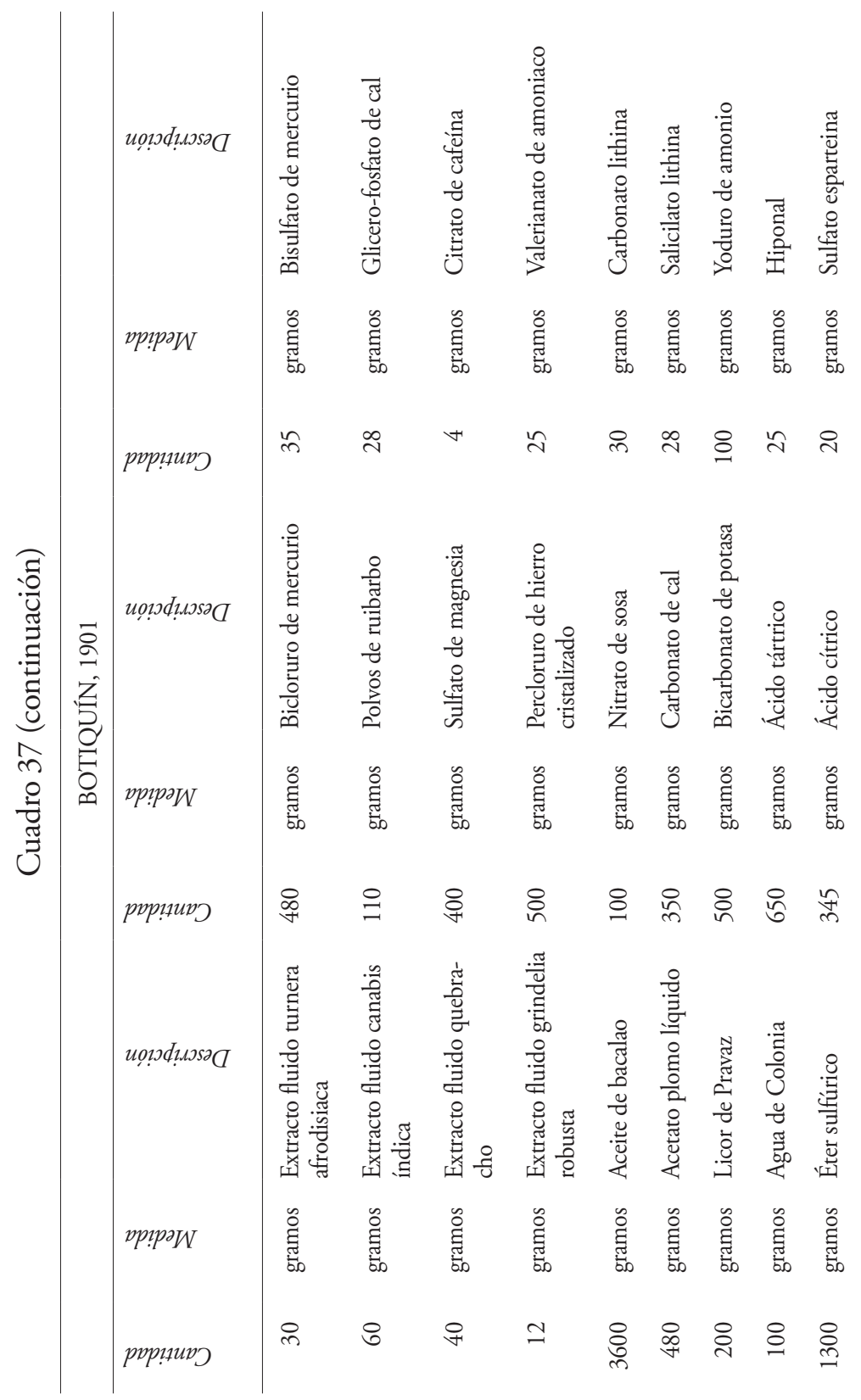




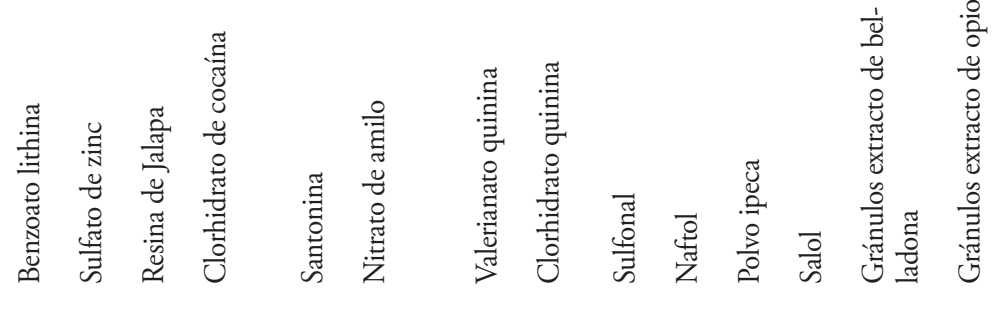

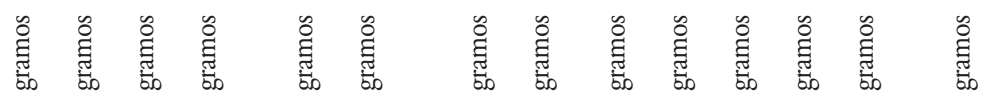

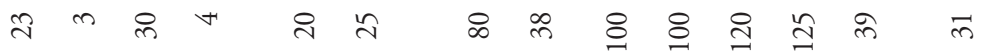

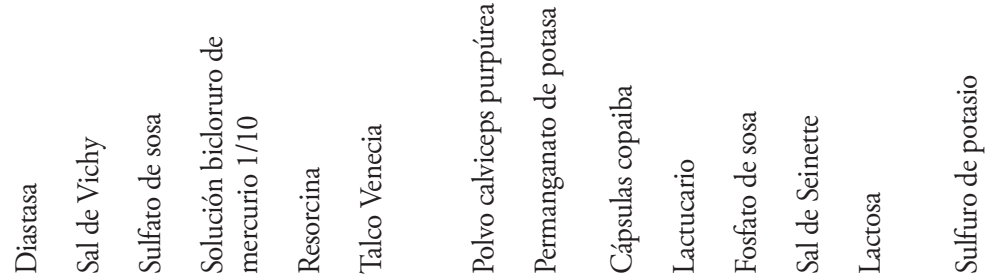

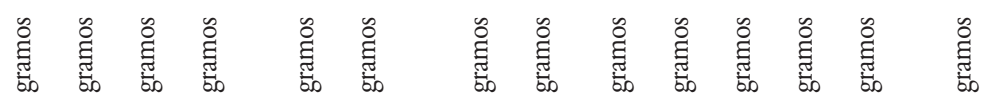
ㅇํ

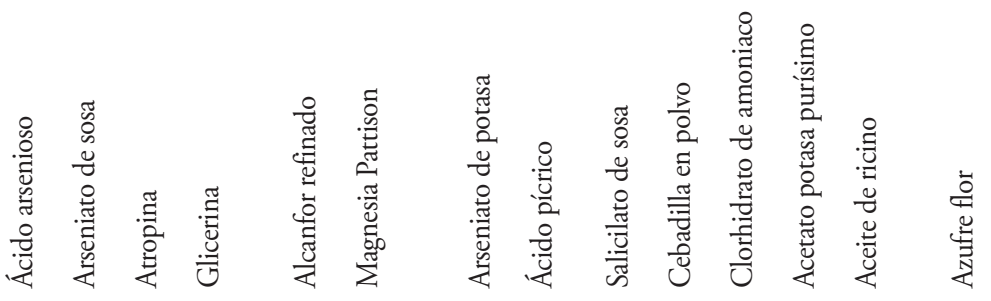

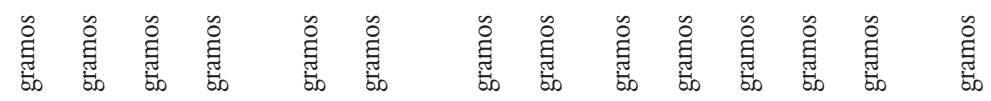

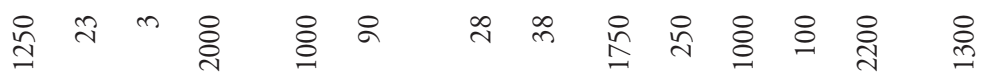




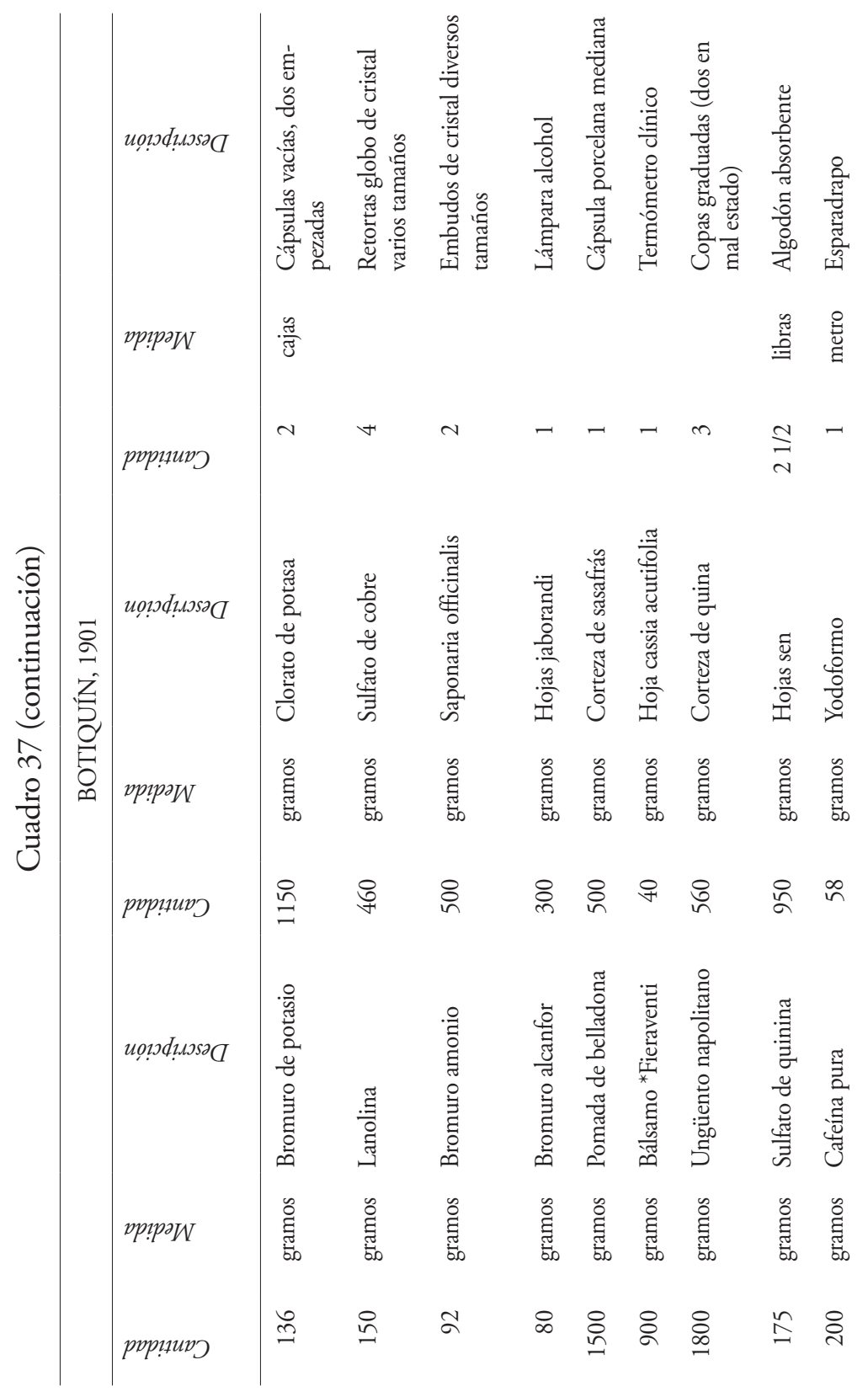




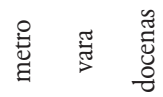

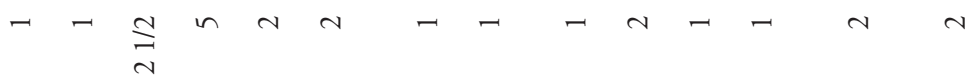

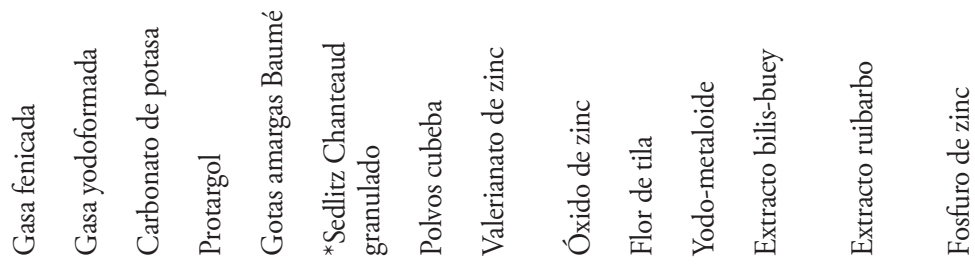

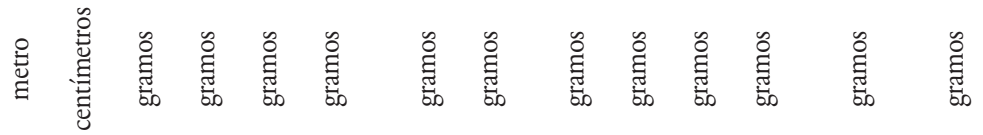

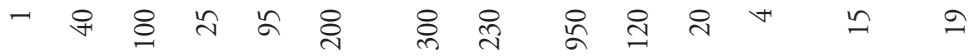

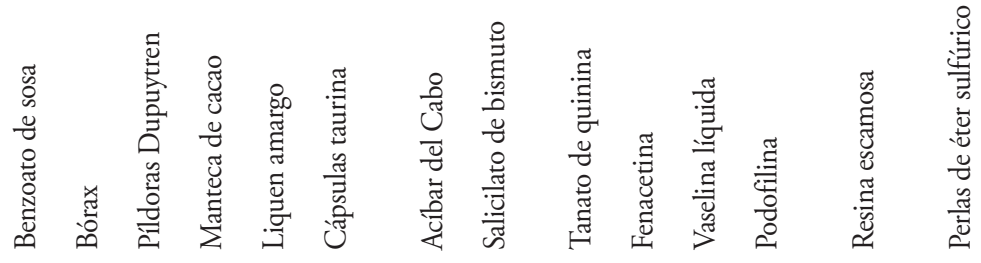

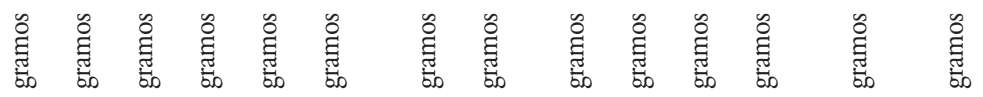

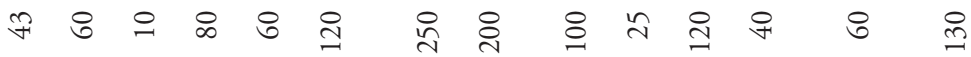




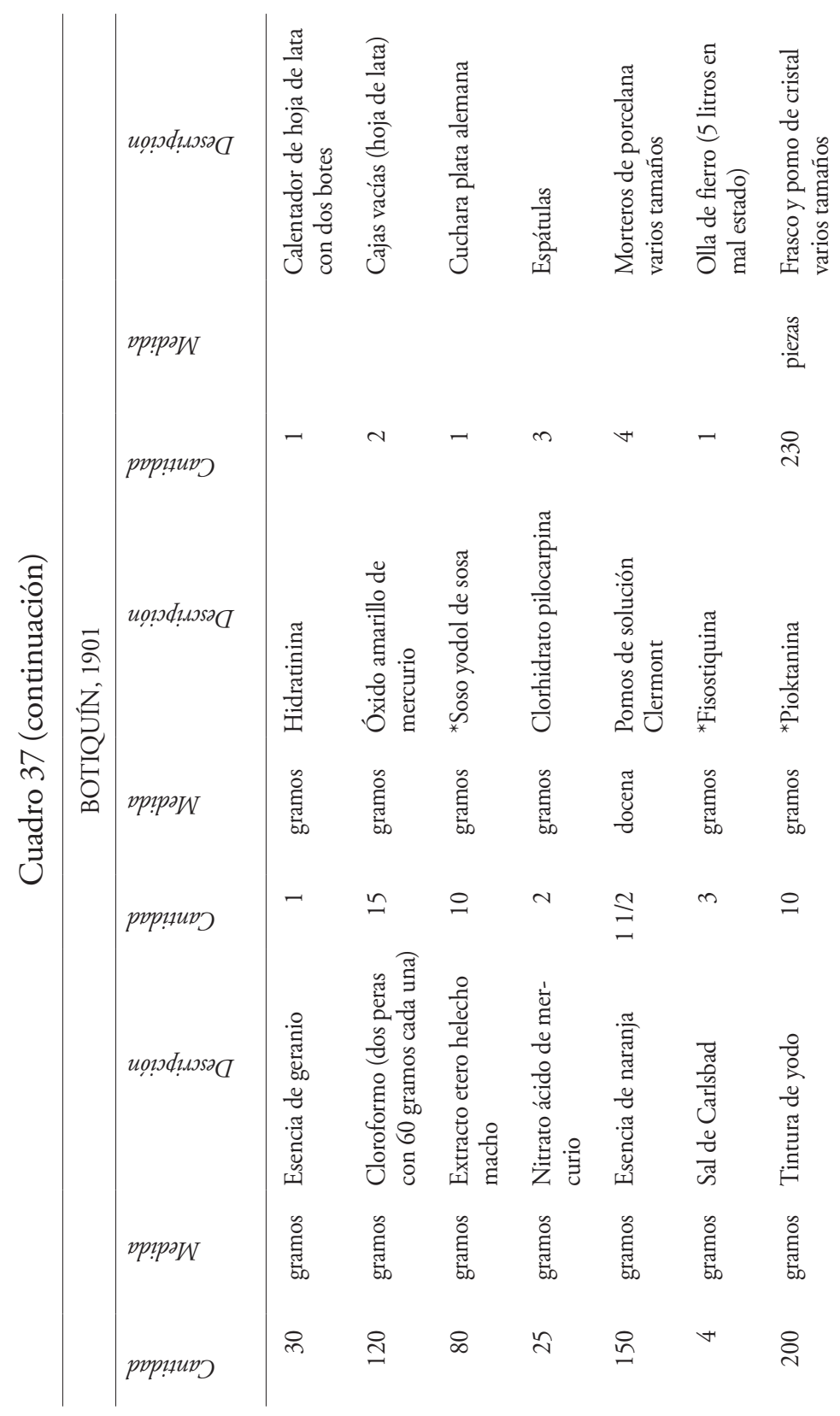



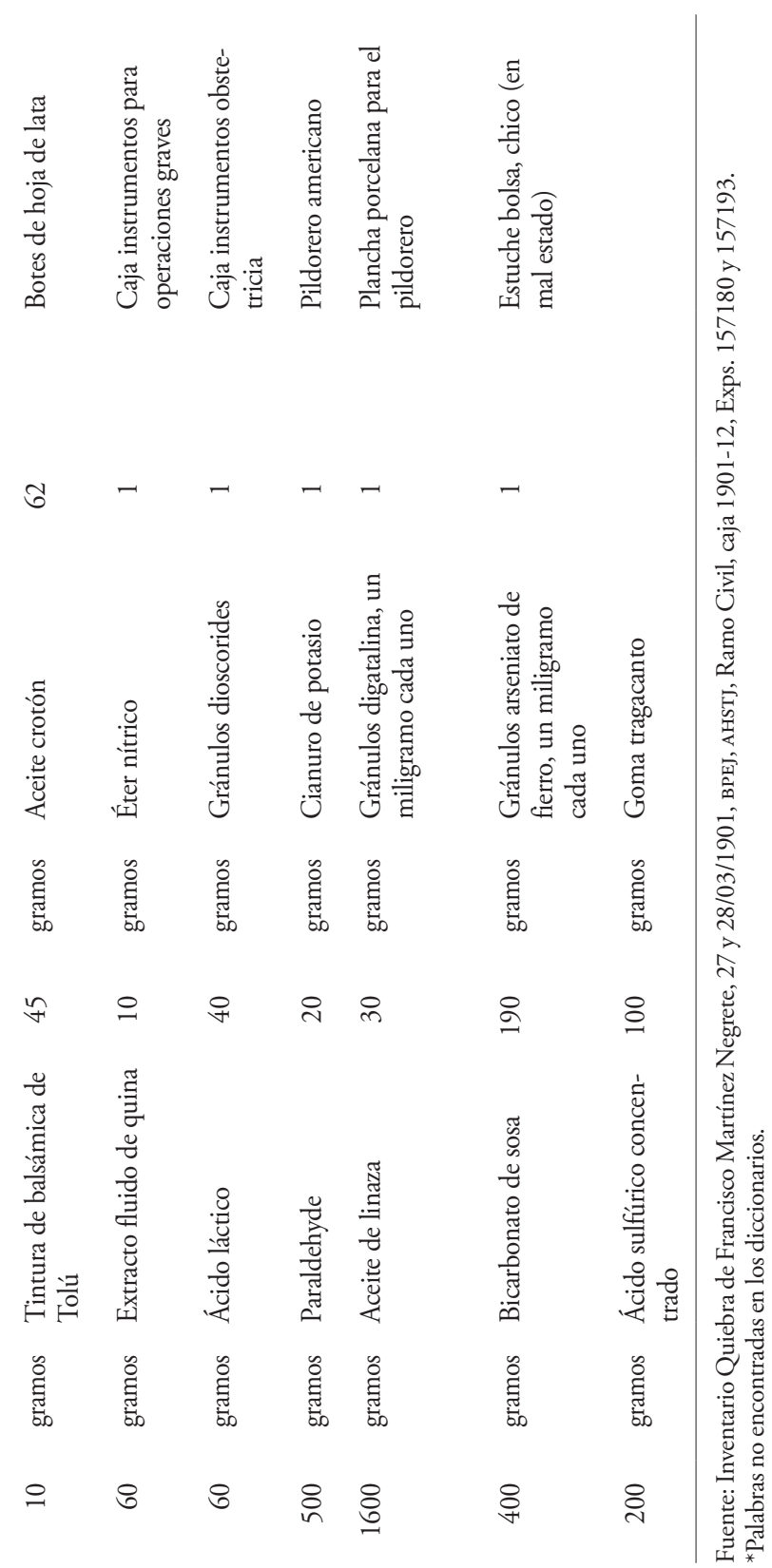
Cuadro 38

\begin{tabular}{|c|c|c|}
\hline \multicolumn{3}{|c|}{ TIENDA, ALIMENTOS 1901} \\
\hline Cantidad & Medida & Descripción \\
\hline 170 & gramos & manteca de cacao \\
\hline 7 & docenas & Obleas \\
\hline 3 & cabezadas & cafés finas \\
\hline $371 / 4$ & piezas & Embutido \\
\hline 39 & paquetes & chicle aromático \\
\hline 1. 540 & kilogramos & Pimienta \\
\hline 1.350 & kilogramos & clavo especie \\
\hline 1. 400 & kilogramos & Canela \\
\hline 3.430 & kilogramos & Almendra \\
\hline 18. 150 & kilogramos & Carbonato \\
\hline 150 & kilogramos & semilla de alfalfa \\
\hline 2.300 & kilogramos & Anís \\
\hline 2. 650 & kilogramos & sagú en grano \\
\hline 640 & gramos & Comino \\
\hline 1.200 & kilogramos & sagú en polvo \\
\hline 2. 070 & kilogramos & Zaratoga \\
\hline 650 & gramos & sal inglesa \\
\hline 4 & docenas & betún americano caja grande \\
\hline 6 & latas & mostaza inglesa polvo \\
\hline $13 / 4$ & docenas & mostaza "Rochester" número 2 \\
\hline 90 & gramos & té fino \\
\hline 4. 360 & kilogramos & pasa California \\
\hline
\end{tabular}




\section{Cuadro 38 (continuación)}

\begin{tabular}{|c|c|c|}
\hline \multicolumn{3}{|c|}{ TIENDA, ALIMENTOS 1901} \\
\hline Cantidad & Medida & Descripción \\
\hline 2 & kilogramos & raíz de zarzaparrilla \\
\hline 1900 & gramos & azúcar granulada \\
\hline 250 & gramos & garbancillo para huarache \\
\hline 7. 100 & kilogramos & Lenteja \\
\hline 17.800 & kilogramos & Camarón \\
\hline 19.500 & kilogramos & azúcar de primera \\
\hline 13 & kilogramos & café en grano \\
\hline 11 & kilogramos & azúcar en polvo \\
\hline 223 & kilogramos & sal de las islas \\
\hline 960.300 & kilogramos & Panocha \\
\hline 15.350 & kilogramos & queso seco \\
\hline 2. 400 & kilogramos & Macarrón \\
\hline 15 & kilogramos & manteca \\
\hline 26.200 & kilogramos & granillo de primera \\
\hline 5.700 & kilogramos & aceite de almendra corriente \\
\hline 42.950 & kilogramos & chile huajillo \\
\hline 48.5 & kilogramos & Harina \\
\hline 40.700 & kilogramos & harina (tomada) \\
\hline 3 & latas & $\begin{array}{l}\text { aceite de comer español } 5 \mathrm{~kg} \text { cada } \\
\text { una }\end{array}$ \\
\hline 7. 400 & kilogramos & aceite de comer corriente \\
\hline 4.500 & kilogramos & chile pasilla \\
\hline 42.450 & kilogramos & arroz "La Fortuna" \\
\hline
\end{tabular}




\section{Cuadro 38 (continuación)}

TIENDA, ALIMENTOS 1901

\begin{tabular}{|c|c|c|}
\hline Cantidad & Medida & Descripción \\
\hline 2 & pomos & cristal con ciruela pasa \\
\hline 7 & pomos & mostaza francesa \\
\hline 4 & pomos & Pickles \\
\hline 6 & pomos & Aceitunas \\
\hline 1454 & piezas & Huevos \\
\hline 2. 150 & kilogramos & Chá (Té en portugués) \\
\hline 5 & kilogramos & Chía \\
\hline 4 & kilogramos & Linaza \\
\hline 1 & kilogramo & café en polvo \\
\hline 4. 900 & kilogramos & aceite de comer fino \\
\hline 1.2 & kilogramos & aceite de comer corriente \\
\hline 300 & gramos & aceite de almendras fino \\
\hline 79 & piezas & nueces moscadas \\
\hline 66 & latas & Salmón \\
\hline 32 & latas & Ostión \\
\hline 26 & latas & ciruela pasa \\
\hline 50 & latas & jamón americano \\
\hline 5 & latas & Sardinas \\
\hline
\end{tabular}

Fuente: Inventario Quiebra de Francisco Martínez Negrete, 27 y 28/03/1901, BPEJ, AHSTJ, Ramo Civil, caja 1901-12, Exps. 157180 y 157193 
Cuadro 39

TIENDA, BEBIDAS, 1901

\begin{tabular}{|c|c|c|}
\hline Cantidad & Medida & Descripción \\
\hline $1211 / 2$ & botellas & cognac "Exposition" \\
\hline 3 & botellas & vino de uva blanco \\
\hline $41 / 2$ & botellas & Cognac \\
\hline 7 & botellas & catalán superior \\
\hline un/sexto & docenas & cerveza especial "La Perla" \\
\hline 5 & botellas & agua de Florida \\
\hline $341 / 2$ & botijas & vino de membrillo \\
\hline 3 & botijas & vino mezcal amargo \\
\hline $102 / 3$ & botijas & vino de toronjil \\
\hline 2 & botijas & vino de nogal \\
\hline 12 & botijas & vino pechuga almendrado \\
\hline $131 / 4$ & botijas & vino de cuastecomate \\
\hline 3 & botijas & extracto de membrillo \\
\hline $251 / 2$ & botijas & vino Tequila \\
\hline 8 & cuartillos & de alcohol \\
\hline 3 & cuartillos & vino pechuga almendrado superior \\
\hline 72 & cuartillos & vinagre de yema \\
\hline $41 / 4$ & cuartillos & vino de nogal \\
\hline $11 / 4$ & cuartillos & jerez amontillado ańejo \\
\hline $11 / 2$ & cuartillos & vino anisado \\
\hline 15 & botellas & cognac "Lafontaine" \\
\hline 6 & botellas & cognac "Gladiator" \\
\hline
\end{tabular}


Cuadro 39 (continuación)

TIENDA, BEBIDAS, 1901

\begin{tabular}{rll}
\hline Cantidad & Medida & Descripción \\
\hline 5 & botellas & agua de Florida \\
3 & botellas & vino tinto torcido \\
$81 / 2$ & botellas & vino cirial \\
2 & botellas & vino de uva para consagrar \\
3 & botellas & vino de uva superior \\
56 & botellas & vinos generosos \\
7 & botellas & vinagre de Castilla \\
20 & botellas & vino tinto "Rioja" fino \\
$51 / 2$ & botellas & vino tinto "Zinfandel" \\
19 & botellas & vino "San Juan" \\
11 & botellas & cerveza "Perla" doble
\end{tabular}

Fuente: Inventario Quiebra de Francisco Martínez Negrete, 27 y 28/03/1901. BPEJ. AHSTJ, Ramo Civil, caja 1901-12, Exps. 157180 y 157193 


\section{Cuadro 40}

\begin{tabular}{|c|c|c|}
\hline \multicolumn{3}{|c|}{ TIENDA, CALZADO, 1901} \\
\hline Cantidad & Medida & Descripción \\
\hline 4 & pares & botitas de cabra \\
\hline 7 & pares & botines varios números \\
\hline 4 & pares & botillas de resorte \\
\hline 6 & pares & botines de charol \\
\hline 3 & pares & botines bayos para mujer \\
\hline 1 & par & botas bayas para niña \\
\hline 4 & pares & Babuchas \\
\hline 2 & pares & botín choclo cabra \\
\hline 12 & pares & botín de charol \\
\hline 6 & pares & botín de cabra \\
\hline 6 & pares & choclo charol \\
\hline 1 & par & botines de cabra \\
\hline 1 & par & botines de raso \\
\hline 26 & pares & Chinelas \\
\hline 3 & pares & botines becerro negros \\
\hline 2 & pares & botines bayos \\
\hline $91 / 2$ & pares & Planchas \\
\hline 6 & pares & Huaraches \\
\hline 10 & pares & botines de raso chicos \\
\hline 29 & pares & aretes corrientes \\
\hline 160 & pares & broches mosca \\
\hline
\end{tabular}

Fuente: Inventario Quiebra de Francisco Martínez Negrete, 27 y 28/03/1901, BPEJ, AHSTJ, Ramo Civil, caja 1901-12, Exps. 157180 y 157193 
Cuadro 41

TIENDA, VESTIDO 1901

\begin{tabular}{|c|c|c|}
\hline Cantidad & Medida & Descripción \\
\hline 5 & pares & medias de color marca $18 \times 21$ \\
\hline 12 & pares & medias de color marca $14 \times 16$ \\
\hline 3 & pares & medias de color marca $12 \times 13$ \\
\hline 3 & & pañuelos con figuras \\
\hline 8 & & pañuelos varias clases \\
\hline 14 & & pañuelos grandes de percal \\
\hline 3 & & camisetas finas \\
\hline 4 & & camisetas americanas de franela y color \\
\hline 18 & & camisetas corrientes blancas \\
\hline 9 & & camisetas de color \\
\hline $21 / 2$ & docenas & calcetín negro \\
\hline 3 & pares & medias negras corrientes \\
\hline 1 & par & calcetines de un color \\
\hline 9 & & rebozos finos y corrientes \\
\hline $12 / 3$ & docenas & calcetín negro \\
\hline 1 & docena & medias finas caladas \\
\hline 3 & & corbatas "Regats" \\
\hline 33 & metros & tela alsaciana \\
\hline media & docena & calcetines crema listados \\
\hline 6 & & mascadas chicas \\
\hline 2 & & mascadas de seda grandes \\
\hline 2 & & sombreros sotol \\
\hline
\end{tabular}




\section{Cuadro 41 (continuación)}

TIENDA, VESTIDO 1901

\begin{tabular}{|c|c|c|}
\hline Cantidad & Medida & Descripción \\
\hline 1 & & chal de franela \\
\hline 22 & & frazadas varios colores \\
\hline 6 & & sarapes chicos varios colores \\
\hline 3 & & chamarras de gamuza \\
\hline 3 & & calzoneras de gamuza \\
\hline 1 & & sombrero fino \\
\hline 7 & & pañuelos con bastilla de cambray \\
\hline 1 & caja & Pañuelos \\
\hline
\end{tabular}

Fuente: Inventario Quiebra de Francisco Martínez Negrete, 27 y 28/03/1901, BPEJ, AHSTJ, Ramo Civil, caja 1901-12, Exps. 157180 y 157193.

\section{Cuadro 42}

MISCELANEA Y ABARROTES, 1901

\begin{tabular}{|c|c|c|}
\hline Cantidad & Medida & Descripción \\
\hline 192 & & pizarrines de leche \\
\hline 176 & & pizarrines de piedra \\
\hline 10 & & Naipes "Campana” \\
\hline 23 & & Naipes “Águila” \\
\hline 115 & & jabones de Zapotlán de 3 1/2 onzas \\
\hline 768 & & panes de jabón de Zapotlán 1 onza \\
\hline 1063 & & panes de jabón del norte de $11 / 8$ onzas \\
\hline 6 & & vasitos de cristal grueso \\
\hline
\end{tabular}


Cuadro 42 (continuación)

\begin{tabular}{|c|c|c|}
\hline \multicolumn{3}{|c|}{ MISCELANEA Y ABARROTES, 1901} \\
\hline Cantidad & Medida & Descripción \\
\hline 9 & & medios cartuchos \\
\hline 5 & & vasitos de vidrio \\
\hline 3 & & platos finos esmaltados \\
\hline $11 / 2$ & & vidrios grandes franceses \\
\hline 1 & caja & jabón de Sayula de 1 onza \\
\hline 264 & & velas parafina \\
\hline 6 & $\begin{array}{l}\text { decenas } \\
(\text { sic })\end{array}$ & garbanzo grueso \\
\hline 1 & & Gamuza \\
\hline 6 & & vasitos de cristal de $1 / 4$ \\
\hline 4 & & saleros azules \\
\hline 6 & & Pomos \\
\hline 5 & & mechas para lámpara "Rochester" número 5 \\
\hline 8 & & vasos con asa de medio cuartillo \\
\hline 1 & & vaso con asa de $3 / 4$ de cuartillo \\
\hline 11 & & vasos de 1 cuartillo \\
\hline 8 & & vasos de 3 cuartillos \\
\hline 6 & & vasos verdes de $1 / 2$ cuartillo \\
\hline 5 & & vasos (cartuchos) con asa \\
\hline 25 & & tazas con porcelana finas \\
\hline 17 & & tazas bola floreo \\
\hline 192 & & dedales de metal \\
\hline
\end{tabular}


Cuadro 42 (continuación)

MISCELANEA Y ABARROTES, 1901

\begin{tabular}{|c|c|c|}
\hline Cantidad & Medida & Descripción \\
\hline 77 & & Entorchados \\
\hline 34 & & cuerdas de guitarra \\
\hline 2 & & jabones fenicados \\
\hline 2 & & peines marfil grandes \\
\hline 13 & & peines marfil chicos \\
\hline 4 & & tijeras marca 75 \\
\hline 87 & & jabones de olor de un precio \\
\hline 29 & & jabones de olor de otro precio \\
\hline 5 & & peines de goma \\
\hline
\end{tabular}

Fuente: Inventario Quiebra de Francisco Martínez Negrete, 27 y 28/03/1901, BPEJ, AHSTJ, Ramo Civil, caja 1901-12, Exps. 157180 y 157193. 


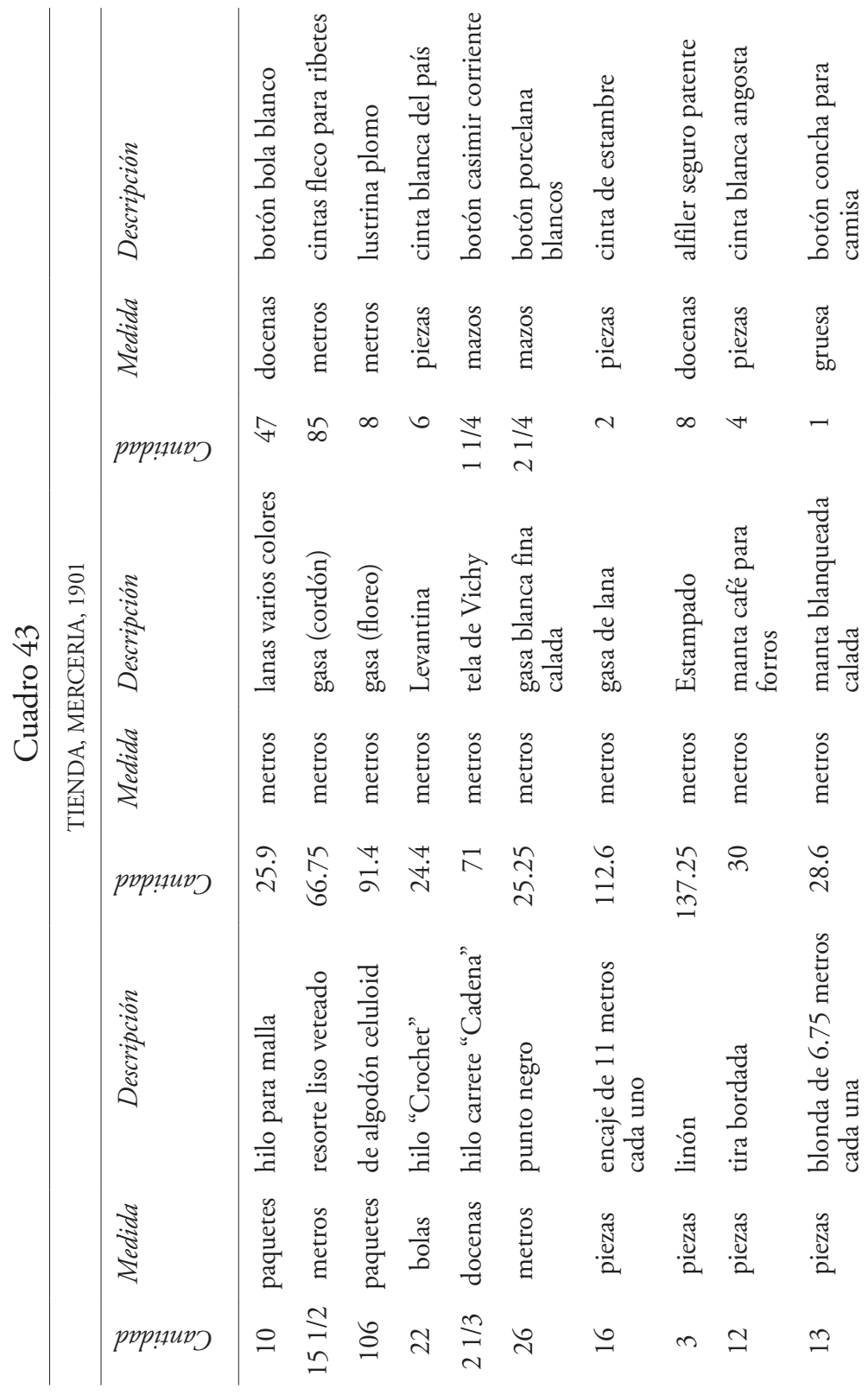




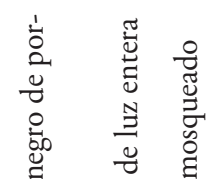

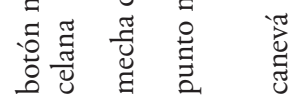

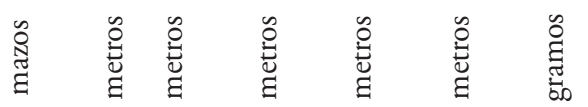

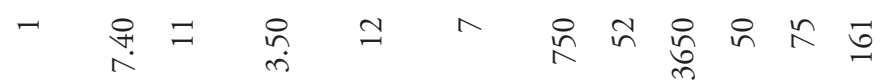

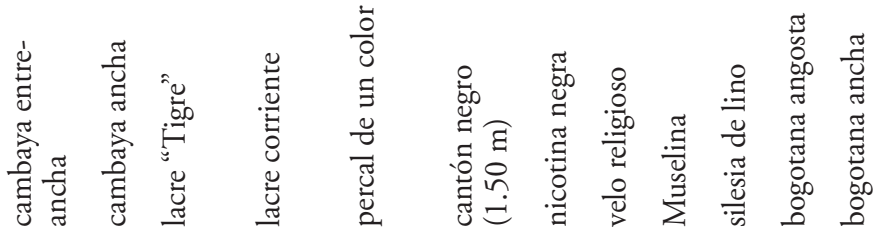

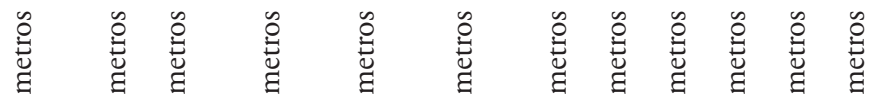

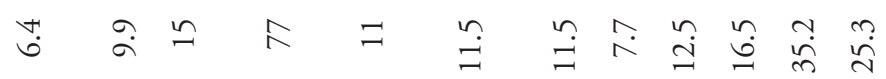

\begin{tabular}{ll}
$n$ & \multicolumn{0}{c}{} \\
$\tilde{y}$ & $\frac{\pi}{4}$
\end{tabular}

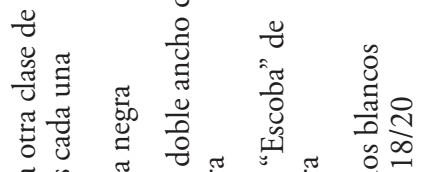

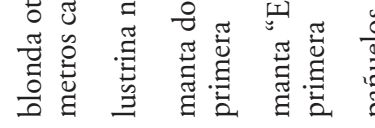

苞

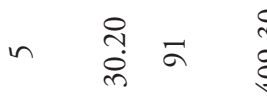

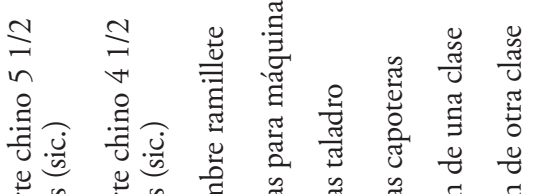

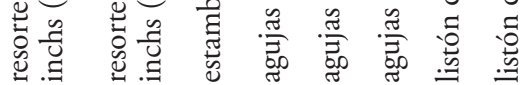

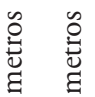

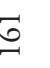




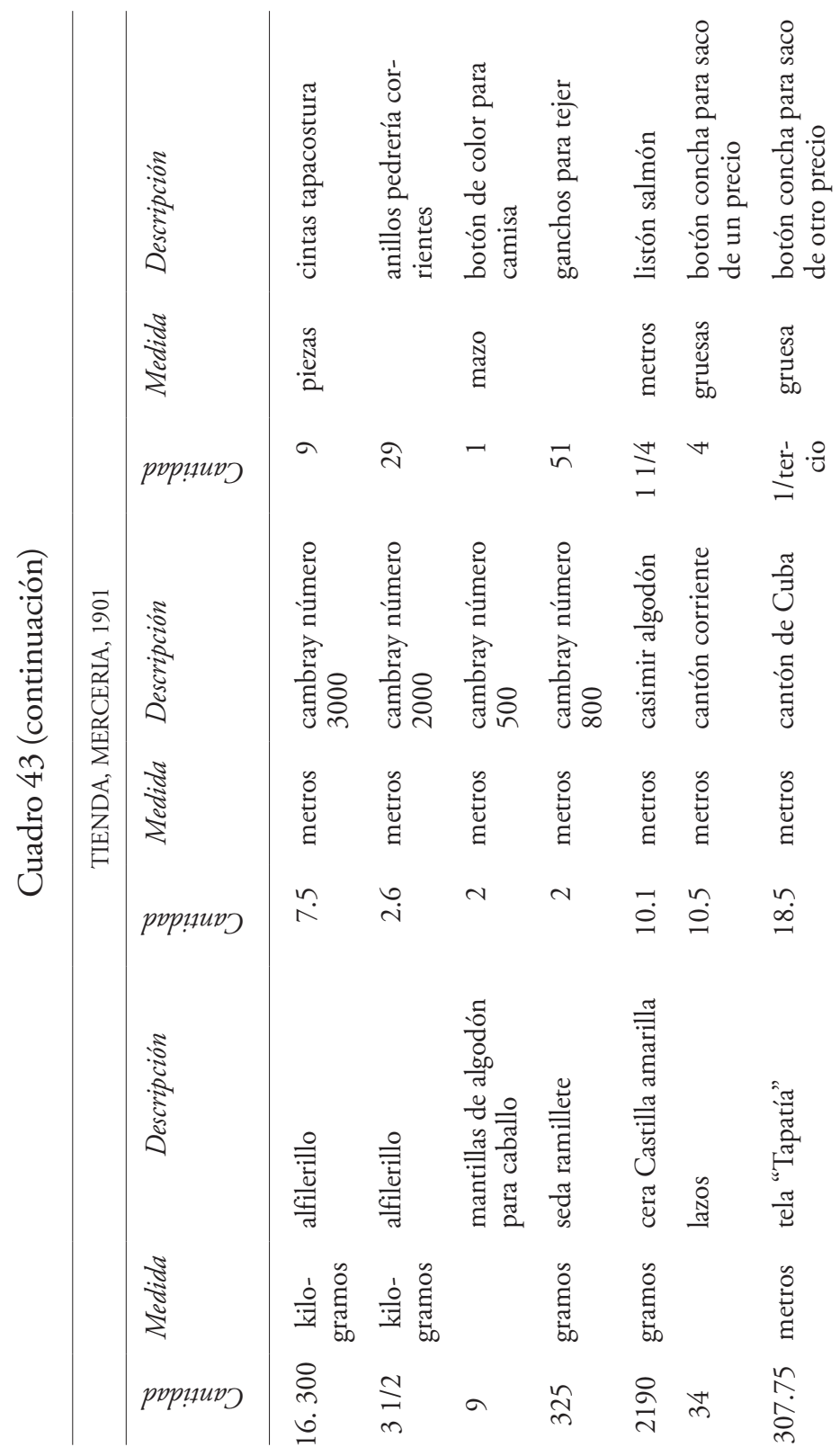




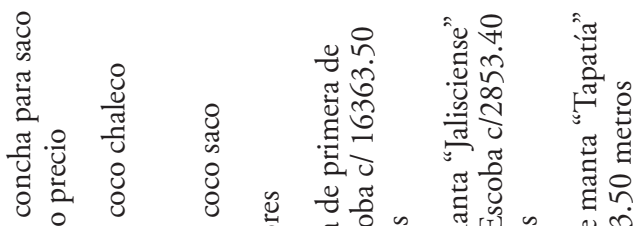

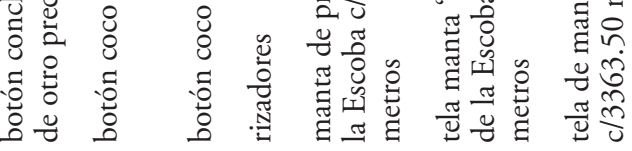

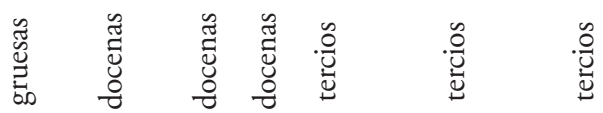

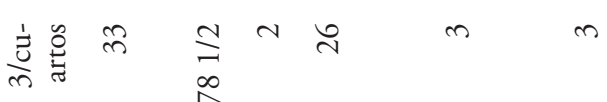

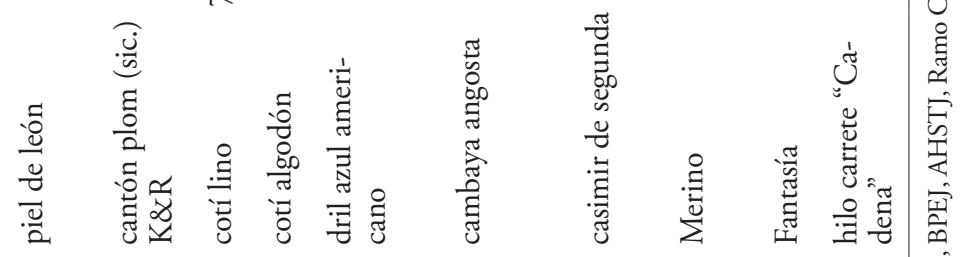

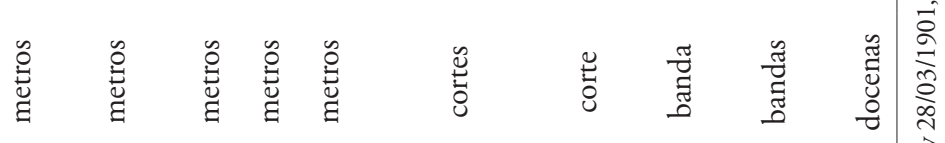

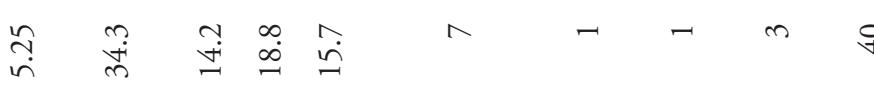

아 $\frac{\hat{y}}{\hat{v}}$

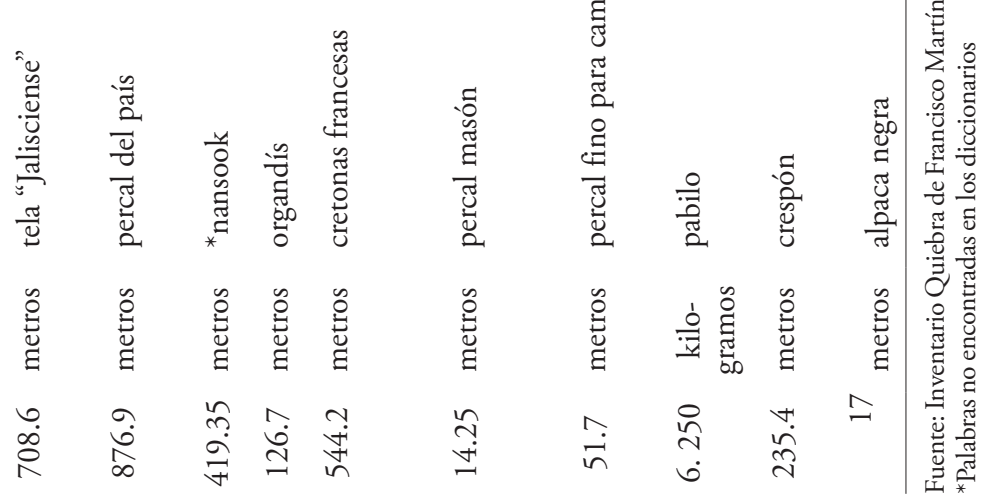


Cuadro 44

TIENDA, PAPELERÍA, 1901

\begin{tabular}{|c|c|c|}
\hline Cantidad & Medida & Descripción \\
\hline 9 & manos & papel de envoltura \\
\hline 3 & resmas & $41 / 2$ manos papel de estraza planchado \\
\hline 2670 & & sobres blancos chicos \\
\hline 1120 & & sobres blancos grandes \\
\hline 990 & & sobres para carta comunes \\
\hline $13 / 4$ & gruesa & plumas número 120 \\
\hline 1 & gruesa & lápices con borrador \\
\hline 1 & gruesa & plumas "Universal" \\
\hline 72 & & cuadernos para escritura \\
\hline $23 / 5$ & docenas & papel "León" esquela \\
\hline media & docena & papel "Ministro" rayado \\
\hline 35 & & cuadernos papel "Ministro" liso \\
\hline 10 & resmillas & papel rayado a luz \\
\hline $21 / 2$ & resmas & papel catalán para torcer \\
\hline media & resma & papel de lino \\
\hline 3 & resmas & 13 manos papel de imprenta duplo \\
\hline 55 & manos & papel de china ramillete \\
\hline 18 & & cuadernos papel para facturas \\
\hline $41 / 4$ & gruesas & lápices con borrador \\
\hline 830 & & sobres chicos de luto \\
\hline 725 & & sobres grandes blancos \\
\hline 250 & & sobres grandes de luto \\
\hline
\end{tabular}




\section{Cuadro 44 (continuación)}

TIENDA, PAPELERÍA, 1901

\begin{tabular}{cll}
\hline Cantidad & Medida & \multicolumn{1}{c}{ Descripción } \\
\hline $51 / 2$ & manos & papel de china rojo \\
20 & & tinteros "Eureka" \\
21 & & tarjetas para felicitación \\
$171 / 3$ & docenas & lápices sin borrador \\
118 & pliegos & papel plateado y dorado \\
17 & pliegos & papel oropel \\
10 & & lápices cónicos \\
11 & pliegos & papel fantasía \\
35 & & tarjetas de felicitación \\
1 & gruesa & plumas "Universal" \\
\hline
\end{tabular}

Fuente: Inventario Quiebra de Francisco Martínez Negrete, 27 y 28/03/1901, BPEJ, AHSTJ, Ramo Civil, caja 1901-12, Exps. 157180 y 157193 


\section{Cuadro 45}

TIENDA, REMEDIOS Y DROGUERÍA, 1901

\begin{tabular}{|c|c|c|}
\hline Cantidad & Medida & Descripción \\
\hline 1 & caja & cigarrillos "Sublimes" del Buen Tono \\
\hline 1 & hectolitro & raíz de valeriana \\
\hline 770 & gramos & clorato en polvo \\
\hline 600 & gramos & glicerina refinada \\
\hline 620 & gramos & glicerina bidestilada \\
\hline 860 & gramos & ungüento populeón \\
\hline 880 & gramos & ungüento verde \\
\hline 400 & gramos & bálsamo tranquilo \\
\hline 760 & gramos & vaselina blanca \\
\hline 540 & gramos & Amoniaco \\
\hline 520 & gramos & pomada alcanforada \\
\hline 380 & gramos & pomada de belladona \\
\hline 480 & gramos & pastillas de goma \\
\hline 100 & gramos & tintura de benjuí \\
\hline 250 & gramos & pastillas de clorato \\
\hline 300 & gramos & pastillas Santonine \\
\hline 180 & gramos & ácido fénico \\
\hline 40 & gramos & píldoras fierro de Blanchard \\
\hline 100 & gramos & polvos juanes \\
\hline 80 & gramos & polvos calomel \\
\hline 950 & gramos & arsénico blanco \\
\hline 5 & & parches porosos \\
\hline
\end{tabular}


Cuadro 45 (continuación)

TIENDA, REMEDIOS Y DROGUERÍA, 1901

\begin{tabular}{rll}
\hline Cantidad & Medida & \multicolumn{1}{c}{ Descripción } \\
\hline 50 & pomos & Emulsión Scott \\
$11 / 2$ & pomitos & pastillas de orozús \\
150 & & puros "Victorias de Colón" \\
120 & & puros "Cafeteros" \\
150 & & puros "Entreactos" \\
$111 / 2$ & kilogramos & Azarcón \\
100 & kilogramos & tabaco cernido \\
227 & cajetillas & cigarros "Victoria Negra" \\
26 & cajetillas & cigarro berro (sic.) "Buen Tono" \\
748 & manojos & cigarro de hoja \\
280 & gramos & Alcanfor \\
\hline
\end{tabular}

Fuente: Inventario Quiebra de Francisco Martínez Negrete, 25 y 27/03/1901, BPEJ, AHSTJ, Ramo Civil, caja 1901-12, Exps. 157180 y 157193 
Cuadro 46

TLAPALERÍA 1901

\begin{tabular}{|c|c|c|}
\hline Cantidad & Medida & Descripción \\
\hline 9 & cabezadas & de vaqueta \\
\hline 5 & cuartas & alambre fino \\
\hline 9 & cuartas & ( 3 finas curtidas y 6 corrientes) \\
\hline 6 & kilogramos & Almidón \\
\hline $371 / 4$ & paquetes & hilo bola "Cadena" \\
\hline $221 / 6$ & docenas & tazas bola filo \\
\hline $111 / 2$ & docenas & tazas bola blanca \\
\hline $11 / 6$ & docenas & tazas bola blanca ochavada \\
\hline $83 / 5$ & docenas & tazas greca blanca \\
\hline 6 & bombillas & "Rochester" número 3 \\
\hline 1 & bombilla & "Rochester" número 2 \\
\hline 10 & bombillas tubo & media luz \\
\hline 33 & & pizarras grandes \\
\hline 30 & & pizarras chicas \\
\hline 320 & & cartuchos calibre 44 \\
\hline 290 & & cartuchos calibre 38 \\
\hline 4 & docenas & cajitas de fulminantes \\
\hline 1 & paquete & mechas luz entera \\
\hline 4 & gruesas & hornillas de diversas clases \\
\hline 5 & cajitas & hilo bola lacre \\
\hline $43 / 4$ & docenas & platos de porcelana grandes \\
\hline $11 / 3$ & docenas & platos de porcelana chicos \\
\hline
\end{tabular}


Cuadro 46 (continuación)

TLAPALERÍA 1901

\begin{tabular}{|c|c|c|}
\hline Cantidad & Medida & Descripción \\
\hline 1 & docena & copitas de cristal \\
\hline 6 & & cartuchos con asa \\
\hline 6 & & charolas grandes \\
\hline 6 & & charolas medianas \\
\hline 6 & & charolas chicas \\
\hline 2 & & vizagras (sic) con resortes \\
\hline 1 & & candado negro \\
\hline 99 & & sogas de jarcia \\
\hline 16 & kilogramos & Acero \\
\hline 7 & kilogramos & velas de sebo \\
\hline $11 / 2$ & gruesas & cerillo yesca \\
\hline $281 / 4$ & gruesas & cajas cerillo de 70 luces \\
\hline media & gruesa & cajas cerillo resorte de tres \\
\hline $21 / 2$ & gruesas & cajas cerillo seguridad de 1 \\
\hline $11 / 2$ & hectolitro & Salitre \\
\hline 5.500 & kilogramos & sebo en greńa \\
\hline 20 & paquetes & azul ultramar \\
\hline 1 & juego & con 4 piezas platones fierro esmaltado \\
\hline 12 & paquetes & magnesia simple \\
\hline $101 / 3$ & docenas & cajas de bola \\
\hline $113 / 4$ & docenas & mechas rojas anchas \\
\hline $91 / 2$ & docenas & mechas rojas angostas \\
\hline
\end{tabular}


Cuadro 46 (continuación)

\begin{tabular}{|c|c|c|}
\hline \multicolumn{3}{|c|}{ TLAPALERÍA 1901} \\
\hline Cantidad & Medida & Descripción \\
\hline 63 & cajitas & Petardo \\
\hline 12.5 & kilogramos & cera de Campeche \\
\hline $63 / 4$ & docenas & tazas bola blancas chicas \\
\hline $13 / 4$ & gruesas & hornilla hueso \\
\hline 2 & piezas & jarana blanca angosta \\
\hline 1 & pieza & jarana negra \\
\hline 450 & gramos & hule para flechas \\
\hline $35 / 6$ & docenas & cucharas peltre \\
\hline 1 & paquete & velas de estearina \\
\hline 1 & docena & cubiertas $(s i c)$ corrientes \\
\hline 150 & gramos & cáñamo negro \\
\hline 102 & manojos & Ocote \\
\hline 10.500 & kilogramos & Azufre \\
\hline 2.5 & kilogramos & extracto de Campeche \\
\hline 8.150 & kilogramos & *Atincar \\
\hline 38 & paquetes & horquilla invisible \\
\hline $61 / 2$ & cajas & Petróleo \\
\hline 424 & paquetes & en el especiero \\
\hline 139 & arrobas & Leña \\
\hline $11 / 2$ & cajas & Gasolina \\
\hline
\end{tabular}

Fuente: Inventario Quiebra de Francisco Martínez Negrete, 25 y 27/03/1901, BPEJ, AHSTJ, Ramo Civil, caja 1901-12, Exps. 157180 y 157193.

*Palabras no encontradas en los diccionarios. 
Cuadro 47

TIENDA, MUEBLES Y ENSERES, 1901

\begin{tabular}{cl}
\hline Cantidad & \multicolumn{1}{c}{ Descripción } \\
\hline 1 & báscula grande capacidad $400 \mathrm{~kg}$. \\
1 & prensa para copiar \\
1 & mesa para la prensa \\
2 & escritorio negro con banco y tarima \\
1 & armazones en la trastienda \\
1 & mostrador en la trastienda \\
2 & mesa de 2 1/4 metros \\
1 & lámparas gasolina \\
46 & barril para el vinagre \\
1 & damajuanas capacidad 3 botijas c/u \\
1 & aparato con reflector \\
1 & candado para la puerta oriente \\
54 & tripa hule para sacar vino \\
2 & botes alcoholeros \\
46 & botes con llave para el petróleo \\
75 & abrigos azucareros \\
1 & hojas de lata chicas \\
1 & tripa hule para vinos \\
353 & damajuana de dos botijas \\
\hline 33 & medias botellas para cerveza \\
\hline & botellas de 1 1/2 cuartillo \\
\hline &
\end{tabular}




\section{Cuadro 47 (continuación)}

TIENDA, MUEBLES Y ENSERES, 1901

\begin{tabular}{|c|c|}
\hline Cantidad & Descripción \\
\hline 150 & sacos de yute grandes \\
\hline 10 & sacos de yute chicos \\
\hline 20 & costales de raspa \\
\hline 2 & lámparas "Rochester" \\
\hline 2 & aparadores en el mostrador \\
\hline 2 & escaleras de gradas \\
\hline 9 & barriles vacíos \\
\hline 6 & castañas de 6 botijas \\
\hline 1 & romana de libras \\
\hline 1 & báscula de $25 \mathrm{~kg}$. \\
\hline 1 & báscula por libras \\
\hline 1 & plataforma capacidad $15 \mathrm{~kg}$. \\
\hline 1 & plataforma capacidad $20 \mathrm{~kg}$. Vieja \\
\hline 1 & juego pesas de bronce $2 \mathrm{~kg}$. \\
\hline 1 & juego pesas de fierro \\
\hline 1 & pesa licores \\
\hline 1 & mesa para el azúcar \\
\hline 4 & polines de madera \\
\hline 2 & llaves madera para vinos \\
\hline 1 & llave bronce para petróleo \\
\hline 3 & botes grandes para el agua \\
\hline 3 & Tirabuzones \\
\hline
\end{tabular}




\section{Cuadro 47 (continuación)}

TIENDA, MUEBLES Y ENSERES, 1901

\begin{tabular}{|c|c|}
\hline Cantidad & Descripción \\
\hline 2 & Abrelatas \\
\hline 20 & embudos varios tamańos \\
\hline 1 & juego de medidas para líquidos \\
\hline 1 & juego de medidas para áridos \\
\hline 1 & juego de medidas para petróleo \\
\hline 25 & botes petroleros \\
\hline 145 & botes mantequeros \\
\hline 6 & pomos grandes bocales \\
\hline 2 & frascos grandes \\
\hline 333 & cajones jaboneros y vineros \\
\hline 77 & cajones grandes \\
\hline 61 & cajones medianos \\
\hline 19 & botes redondos con tapa grandes \\
\hline 9 & botes redondos con tapa medianos \\
\hline 13 & botes redondos con tapa chicos \\
\hline 33 & abrigos de ropa \\
\hline 4 & candados en las puertas de la tienda \\
\hline 1 & puerta de fierro \\
\hline 1 & chapa inglesa y dos resortes varilla \\
\hline 3 & cajas mantequeras con zinc \\
\hline 1 & mantequera (hoja) \\
\hline 2 & jarras para medir líquidos \\
\hline
\end{tabular}


Cuadro 47 (continuación)

TIENDA, MUEBLES Y ENSERES, 1901

\begin{tabular}{cl}
\hline Cantidad & Descripción \\
\hline medio & hectolitro con su recero \\
2 & medias para granos (sistema antiguo) \\
& varios útiles para la panadería \\
1 & máquina de coser (medio uso) \\
1 & máquina de coser reformada "New National"
\end{tabular}

Fuente: Inventario Quiebra de Francisco Martínez Negrete, 25 y 27/03/1901, BPEJ, AHSTJ, Ramo Civil, caja 1901-12, Exps. 157180 y 157193. 